\title{
STATE NETWORKS AND INTRA-ETHNIC GROUP VARIATION IN THE 2011 SYRIAN UPRISING
}

\author{
forthcoming in Comparative Political Studies \\ Kevin Mazur \\ kevin.mazur@nuffield.ox.ac.uk
}

August 23, 2018

\begin{abstract}
The 2011 Syrian uprising looks, from afar, like a paradigmatic example of ethnically exclusive rule giving way to civil war. The ruling regime is drawn almost exclusively from the Alawi minority and the challengers were drawn heavily from the Sunni majority. But many Sunnis remained quiescent or actively supported the regime. This article argues that variation in revolutionary participation among members of an excluded ethnic group is best explained in terms of the networks states construct across ethnic boundaries. It identifies several forms of linkage that regimes can develop with their subject populations and relates them to variations in local social structure. Drawing on an original dataset of ethnic identity and challenge events in the Syrian uprising, the article quantitatively tests the state networks hypothesis. Its findings suggest that the mechanisms commonly associated with ethnic identity and 'ethnic exclusion' frequently operate upon social boundaries below the ethnic group level.
\end{abstract}

\section{ACKNOWLEDGEMENTS}

For their helpful comments, I thank Ana Arjona, Chris Barrie, Killian Clarke, Loubna El Amine, Mark Beissinger, Kheder Khaddour, Rana Khoury, Luis Schiumerini, Rob Schub, Salam Saadi, Hendrik Spruyt, Maya Tudor, and participants in the Northwestern Comparative Politics and Brasenose College Conflict workshops. This research was financially supported by the Bobst Center for Peace and Justice at Princeton University and a POMEPS Travel-Research-Engagement grant. 
The 2011 Syrian uprising is, at first glance, a textbook case of ethnic civil war. Most members of the Syrian regime are drawn from the Alawi ethnic ${ }^{1}$ group, which constitutes roughly 10 percent of the country's population. The Sunni Arab ethnic group, which constitutes about 70 percent of the population, is little represented in the upper reaches of the regime. From the uprising's very beginning in March 2011, the great majority of challenge to the regime came from Sunni communities, and no demonstrations occurred in Alawi towns or urban neighborhoods. ${ }^{2}$ The combination of Alawi rule and violent challenge by Sunnis is consistent with recent cross-national work demonstrating a robust link between ethnic exclusion and intrastate violence (ex. Wimmer et al., 2009). Yet not all Sunni communities engaged in challenge; many were quiescent, and some hosted counter-demonstrations in support of the regime. Variation among Sunni communities raises a broader theoretical question: why do some members of an excluded ethnic group participate in revolutionary challenge, while others do not?

This article argues that, in many polities, it is not entire ethnic groups that are included or excluded from access to state resources, but smaller units like local communities and individuals. In such polities, intra-ethnic group variation in revolutionary participation is best explained by these sub-ethnic units' inclusion or exclusion from networks of access to central state power and resources. When revolutionary challenge breaks out among members of an excluded ethnic group, the local communities with strong linkages to the state should incline towards quiescence, even if most other

\footnotetext{
${ }^{1}$ Though religious differences are more commonly referred to in the Levantine context as 'sectarian', this article treats them as a sub-type of 'ethnic' identity, where the latter is understood, following Weber, as "a subjectively felt belonging to a group that is distinguished by a shared culture and by common ancestry" (Wimmer, 2013, p. 7). Scholars such as Rogers Brubaker $(2015$, p. 4) have noted that religious identities are distinctive because they more likely to be involved in struggles over the "substantive regulation of public life" than non-religious ethnic identities. Yet Brubaker also notes that this relationship is contingent and that these properties are not unique to religious identities (p. 12). The ambiguities of the religious/national distinction are evident in the Syrian case; Kurds and much of the Arab Syrian opposition were Sunni Muslims, but some Kurdish political actors sought to paint the entire opposition as Muslim Brothers and radical Islamists by claiming that the opposition sought to regulate public life in ways inconsistent with Kurds' secularism and moderate (Sunni) religious practice (Allsopp, 2014, p. 200).

${ }^{2}$ Examples of participation by Alawis abound, but all occur in the relatively anonymous public space of major cities, or in Sunni-majority towns and urban neighborhoods, see section III.
} 
communities sharing their ethnic identity lack such access and engage in contentious action against the state. The literature on ethnic collective action identifies densely networked communities as the key mechanism impelling solidary group action (ex. Roessler, 2016; Habyarimana et al., 2009). This article builds upon that same mechanism, but argues that the social units possessing the relevant network properties are often not entire ethnic groups. Rather, clans, extended families, and towns are more likely to contain such networks and, thus, act in solidarity.

The assumption of a tight correspondence between ethnic identity and network membership has been useful in establishing a broad correlation between ethnic exclusion and civil war, but regime-society networks cross ethnic boundaries in many polities; where the boundaries of ethnic identity and networks into the state diverge, state networks exert considerable force in determining patterns of challenge. Scaling down to sub-ethnic group units reveals that the smooth surface of ethnic solidarity in collective action that appears from afar, when challengers are drawn overwhelmingly from a single ethnic group, is jagged when viewed up close.

The 2011 Syrian uprising is amenable to both the smooth, macro-level view of ethnic conflict and a meso-level view of inconsistent ethnic mobilization - participants in the uprising were overwhelmingly Sunni, with far lower levels of participation by Alawis and other non-Sunnis, but there was enormous variation in participation among Sunnis; some mobilized against the regime, some remained on the sidelines, and others mobilized in support of the regime. This article documents intra-Sunni ${ }^{3}$ variation in participation, drawing on highly disaggregated data linking revolutionary events with town characteristics, including levels of state employment, public services, and ethnicity. It accounts for the tension between the macro and meso views by reference to the ties linking local Sunni communities to the Alawi-dominated regime. Sunni communities with tribal social structure and historical intermediary relations to the regime, as well as those urban

\footnotetext{
${ }^{3}$ Intra-group variation among 'included' ethnic minorities, such as Alawis, Christians, and Druzes, as well as (Sunni non-Arab) Kurds, raises important theoretical issues. Because the ethnic powersharing literature focuses on 'excluded' groups' propensity for rebellion, however, the empirical focus here is intra-Sunni Arab variation.
} 
communities with high levels of state employment or patronage, were far less likely to participate in the uprising. In other words, challengers came overwhelmingly from a single ethnic group, but considerable variation existed within that group, and the factors impelling challenge fit unevenly into ethnic boundaries. This is not an entirely novel claim about the Syrian uprising — scholars have noted Sunni individuals and populations that remained on the sidelines or the uprising or actively stood with the regime (ex. Droz-Vincent, 2014, p. 41). Yet these threads of Sunni variation have not previously been drawn together in a systematic fashion, nor related to the broader literature on ethnic exclusion and conflict.

In explicating state-society linkages that cross ethnic boundaries and their role in structuring revolutionary contention, this article suggests that research seeking to understand the 'ethnic' component of revolutions and intrastate violent conflict must go beyond elaborating the contours of ethnic boundaries and attend to the characteristics of networks that often cross ethnic lines. This disaggregated picture of state-society ties and their unraveling in violent conflict also offers a vantage point on how an ethnically exclusive, minority regime can retain power-by forging ties to communities across ethnic boundaries.

The article proceeds as follows: The first section develops a theoretical account of how state networks influence patterns of contentious challenge in revolutionary situations, and the following section describes the topography of networks and ethnic boundaries in Syria. The third section presents original, highly disaggregated data on the Syrian social contract and the events of the 2011 uprising, then tests the state networks hypothesis statistically. A fourth section examines the mechanisms channeling local-level solidary action and quiescence.

\section{THEORY}

This article focuses on a particular form of contentious challenge to incumbent state authorities: revolutionary situations before state breakdown. Revolutionary situations begin with the onset of multiple sovereignty, when societal challengers claim the legitimate right to rule, and end 
when a single sovereign power is restored (Tilly, 1973, p. 441). While significant work has been done on intra-ethnic group variation in routine, institutionalized politics (ex. Koter, 2016) and violence during civil war (ex. Kalyvas, 2006), less attention has been directed towards the subnational mechanisms driving escalation from non-violent contention to sustained intra-state violence. This constitutes a lacuna in the literature because insights from studies of institutional politics have limited explanatory power in polities where political order is secured primarily through informal agreements outside formal institutions (Roessler, 2016, p. 12), and challenge follows a fundamentally different logic once state control breaks down; the cleavages that structured pre-civil war social life are less binding on social actors once issues of territorial control and tactical military concerns take on central importance (Kalyvas 2006, p. 22).

To better conceptualize the role of ethnic identity in this middle phase, between routine politics and civil war, this article classifies local communities within a polity according to (1) whether they share the ethnic identity of the regime, and (2) whether they are part of the regime's patronage networks (see figure 1). The upper left quadrant of figure 1 contains social actors sharing the ethnic identity of the regime who fall in its patronage networks, the 'doubly included'. The lower right quadrant contains actors not sharing the regime's ethnic identity and excluded from patronage networks, the 'doubly excluded'. These two groupings constitute the stereotypical image of an ethnically exclusive regime - a minority ethnic group gets all the spoils of rule and the excluded majority gets little. Yet social actors can fall in the off-diagonal boxes of the matrix, being 'ethnically included non-clients' or 'ethnically excluded clients'. 
Figure 1: Possible relationships of a local community to an ethnically dominated state

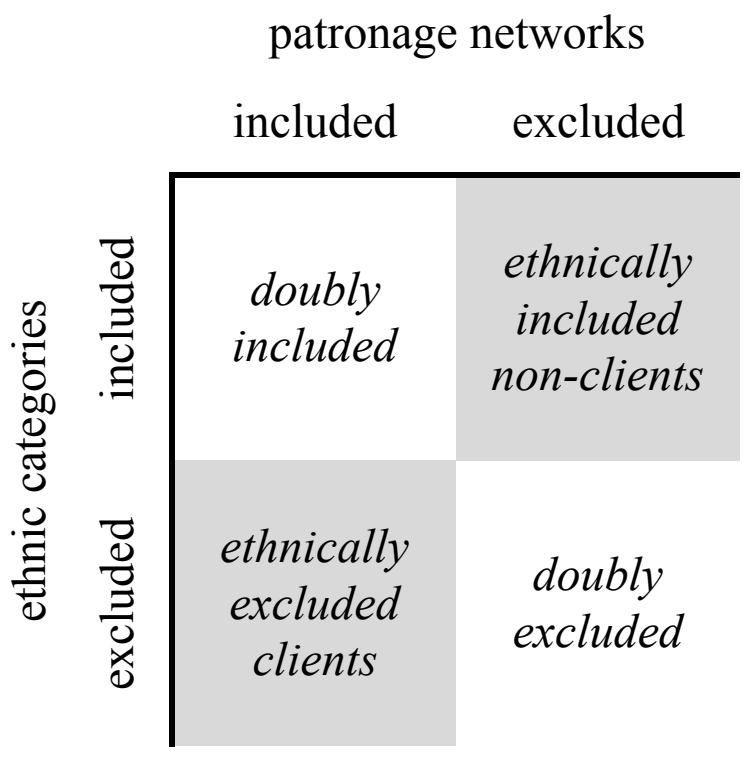

The state linkage hypothesis advanced here holds that variation in revolutionary participation among ethnically excluded actors is best understood in terms of group members' differential access to state networks; the doubly excluded should participate at far higher rates than ethnically excluded clients. This argument builds upon mechanisms identified in the ethnic powersharing literature, which examines the role of informal patron-client networks in linking local communities to the state. Developed based upon sub-Saharan African polities where formal state institutions are of minor importance to actual political life, this literature describes ruling regimes that are coalitions of ethnic elites. In such situations, "ruling Big Men strike alliances with those embedded in rival ethnic groups” (Roessler, 2016, p.14). 'Big Man' intermediaries are able to use their network ties to a significant portion of their co-ethnics to redistribute to and demobilize the latter, making regimes that include the 'Big Men' of many ethnic groups see lower rates of armed rebellion than narrow, ethnically exclusive regimes (Roessler, 2016, p. 46). Whereas the ethnic powersharing literature assumes that ethnic boundaries and patronage networks are coterminous, cross-ethnic patronage ties exist in many polities and play a key role in demobilizing some members of the 'excluded' ethnic group during revolutionary situations. To further unpack this argument, the rest of this section explores the assumptions underlying the notion of solidary ethnic group action. 
The link between ethnic exclusion and challenge in the ethnic powersharing literature depends upon two separate premises: (1) dense social networks generate solidarity and collective action, and (2) these networks are housed almost entirely within an ethnic group. The state networks account advanced here accepts the first premise but argues that the second often does not hold empirically.

The first premise, that networks can facilitate solidarity and mobilization, is based upon the empirical observation that members of the same network are spatially proximate to one another, share much cultural material, have similar preferences, and, most importantly, develop norms of reciprocity (Habyarimana et al., 2009, ch. 4; Roessler, 2016, p. 50). The mechanisms underpinning this finding are developed more extensively in the literature on social capital and collective action. James Coleman (1988, p. S107) argues that dense network ties give rise to norms and trust among network members because they enable sanctioning among group members without direct monitoring, facilitating "the proliferation of obligations and expectations."

The second premise, that networks and ethnic groups are coterminous, is standard in the literature on ethnicity and public goods provision, and is employed in the study of violent conflict on ethnic lines (ex. Lyall, 2010, p. 15). Work employing this assumption has contributed greatly in making sense of the cross-national patterns identified by Wimmer et al. (2009), but the assumption stands at variance with empirically observed intra-ethnic group variation-Koter (2016, p. 35-6) documents how, in Senegal and other West African states, political parties subcontract voter mobilization to intermediaries with "hierarchical ties" to influential members of local communities, and Baldwin (2016, p. 46-8) notes the tendency of sub-Saharan political leaders to develop clients across ethnic boundaries.

The second premise is also conceptually untenable. There is significant slippage between the empirical finding that small groups sharing an ethnic identity cooperate better and the common interpretation of this work, that millions of people sharing the same identity would have similar 
facility in cooperating based upon their identity alone (Corstange, 2016, p. 40). The properties of solidary groups identified by Habyarimana et al. (2009) would accrue to both sub-ethnic kin units and multi-ethnic groups that are densely networked due to factors like spatial clustering and frequent commercial interaction; they would not accrue to populations sharing an ethnic identity but few social or economic ties. The mechanisms identified in the ethnic collective action literature, on close examination, bear this point out — a person might have frequent contact with any members of his or her network regardless of his or her ethnic identity and would not have frequent interaction with coethnics who are not members of that network; actual blood kinship relations obtain only in small pockets of a broader ethnic group; and shared language and cultural material could obtain among members of an ethnically diverse network and do not necessarily obtain among all members of an ethnic group. Coleman's (1988, p. S106) observation that norms of reciprocity should only obtain where sanctioning among group members is possible helps to make sense of this potential disjuncture between ethnic identity and group efficacy; an ethnic identity unassociated with any social tie would not suffice to enforce behavioral norms, removing actors' incentives to act with members of their ethnic group. ${ }^{4}$

The state networks account of intra-ethnic group variation builds upon the notion that dense networks generate solidarity that can underpin mobilization or quiescence, but contends that a tight overlap of network and ethnic group boundaries is a contingent feature of groups in some, but not all, ethnically exclusive polities. In situations where this overlap is incomplete, many local communities below the level of the ethnic group can be expected to have the properties of solidarity commonly attributed to entire ethnic groups and interests diverging from those of other members of their ethnic group. In these polities, ethnically excluded clients will be a population of a non-trivial size and can

\footnotetext{
${ }^{4}$ Ethnic categorization alone can impel action on the basis of fear, hatred, or rational cost-benefit calculation in social systems where ethnic identity significantly influences actors' resource access and life chances, but this is not always the case and needs to be demonstrated empirically (Wimmer, 2013, p. 84-86). Where cross-ethnic patronage networks exist, by definition, social closure along ethnic lines is incomplete; other mechanisms are thus likely to be at play.
} 
be are expected to engage in lower levels of collective action than members of their ethnic group who lack such ties.

State linkage can work on an individual level—functioning as a selective dis-incentive for individuals who personally benefit from state largesse — or a collective level, demobilizing a broad population when a state client constitutes a patron for a local community. This does not mean that all local actors under the patronage of an intermediary to the state will be quiescent; some may benefit very little from their patron's ties, or may have ideological or idiosyncratic reasons to behave at variance with the interests and stance of the group. But, to the extent that state-linked populations do engage in challenge, powerful social actors have an interest in preserving their ties to the regime that would be imperiled by the contentious actions of contention by mass actors under their control. This produces an additional observable implication of the state networks theory: intermediaries between the state and local communities should act to minimize challenge in areas under their control and sanction community members who engage in challenge.

State strategies of including intermediaries from other ethnic groups create other governance challenges for incumbent regimes. Intermediaries have incentives to divert state resources, whether for their own consumption or to mount a challenge to the regime (Roessler, 2016, p. 5). However, the risk that intermediaries would use state-bestowed resources to challenge the regime is greater in situations of elite powersharing — under which parts of the coercive apparatus, like major military battalions or security agencies are given over to an elite ethnic outsider - than when town-level or regional elites are included in the legislature or the lower levels of security apparatus networks dominated by members of a single group..$^{5}$

\footnotetext{
${ }^{5}$ The latter situation was the case in Syria, but even this form of linkage created principal-agent problems, albeit at lower levels of governance. Because of the autonomy it afforded to local networks like tribal leaders and heads of influential families, the Syrian regime was compelled to tolerate local smuggling rings enmeshed with its security services and was forced to rely on local elites to police violent crimes and resolve inter-family disputes (Barout, 2012, p. 237). Yet these intermediaries lacked access to forms of power that could be used to pose a serious threat to the incumbent regime. This is evident in the forms of challenge observed when intermediaries broke
} 
The state networks theory seeks to explain patterns of challenge directed at an incumbent regime from a sufficiently small ethnic group (or set of groups) that the regime needs to forge ties with social actors across ethnic boundaries to remain in power. There is no exact cutoff for what constitutes a sufficient level of ethnic exclusion for the state networks theory to apply, in part because regimes drawn largely from a minority ethnic group have incentive to hide the ethnic composition of their inner circle and deny that ethnic identity matters in to political and social life. Regimes excluding half of their total population on an ethnic basis are particularly likely candidates to employ cross-ethnic networks to manage challenge. One effort to quantify exclusion is the Ethnic Power Relations (EPR) database, which measures ethnic group-level exclusion from access to central state power for every country-year from 1946 to 2005. Governments that exclude more than half of their population on an ethnic basis constitute 11 percent of all EPR country-years (Wimmer et al. 2009).

In addition to contemporary Syria, Ba thist Iraq and Sudan under the National Islamic Front excluded a majority of their populations and offer clear examples of networks forged across ethnic lines. The Sunni Arab-dominated Iraqi regime conducted a ruthless assault on Shia communities following the end of the 1991 Gulf War, but promptly afterwards began reinforcing ties to Shia notables on clientelistic tribal lines (Baram, 1997, p. 18); in Sudan, the riverine Arab-dominated regime forged linkages to non-Arab and nomadic and populations to suppress the First Darfur Rebellion of the early 1990s (Roessler, 2016, ch. 5). These cases suggest that the mechanisms identified in the Syrian case are likely at play under many other minority-dominated regimes facing revolutionary challenge.

with the regime in late 2011 and early 2012, usually following regime violence against civilians; they and the communities to which they formerly linked the regime used mostly light weapons and engaged in scattered attacks on state forces, rather than peeling entire elite divisions off from the military and security forces (Barout, 2012, p. 254). 
To understand how cross-ethnic networks coexisted with a minority-dominated regime in Syria, the next section explores the historical factors shaping the complex of ethnic identity and state networks in Syria.

\section{ETHNICITY, NETWORKS, AND SOCIAL STRUCTURE IN SYRIA}

Unlike the 'Big Man' intermediaries identified in the ethnic powersharing literature, statesociety ties in Syria frequently, and necessarily, cross ethnic boundaries. The simultaneous favoritism of the regime's ethnic group and significant intermediary linkages into the 'excluded' majority were possible in Syria because of the internal variation within the majority Sunni ethnic group.

\section{Ethnic boundaries and social structure}

The relevant ethnic identities in Syria are a matrix of religion and national identity. Religiously, the vast majority of Syrians can be classified as Sunni Muslims, Christians or members of one of several heterodox Islamic religions. The latter category includes the Alawis (the group from which President Bashar al-Asad and many other regime figures are drawn), Druzes, and Ismailis. In terms of national identity, the majority of the population is Arab, with significant nonArab Christian and Kurdish populations in the country's northeast; nearly all Kurds are Sunnis. Sunni Arabs constitute roughly 72 percent of the total Syrian population, Alawis 10 percent, Kurds 8 percent, Arab Christians 5 percent, Druzes two percent, and other minorities the remaining three percent (Courbage, 2007, p. 189).

Ethnic groups in Syria, particularly Sunni Arabs, lack the properties of cultural homogeneity, spatial clustering and shared political legacies observed by theorists of ethnic powersharing in subSaharan Africa. Nearly all Syrians share a common language of Arabic, and there is enormous cultural and economic diversity among Sunni Arabs, even among spatially proximate communities (Syrian Kurds by and large speak Arabic, due in no small part to the Ba 'th policy of cultural discrimination against Kurds that includes schooling in Arabic only.). The city of Hama, for 
example, is almost entirely Sunni Arab, and home to historical urban landlord classes, artisans, merchants, and laborers. In its immediate periphery are Sunni peasant villages and villages of formerly nomadic Sunni Arabs retaining tribal social structure. This last distinction, between Sunni Arab populations of tribal and non-tribal background, maps onto whether a population has a recent history of nomadism and is relevant because the regime long cultivated tribal leaders as clients (Batatu, 1999, p. 22). Moreover, Sunni Arabs are not spatially clustered. In the Hama countryside, for example, towns of majority Alawi or Ismaili ethnic identity are interspersed among Sunni towns (see maps in the online appendix). The Sunni peasant communities around Hama are likely to have human capital and cultural practices more similar to their Alawi and Ismaili peasant neighborswhose ancestors were peasants brought out of the nearby mountains by Hamawi (Sunni Arab) landlords during the nineteenth and early twentieth centuries - than their urban co-religionists (Batatu 1999, p. 12).

The diversity of cultural practices and modes of production among Sunni Arab communities was sustained by intermediary relations that have been central to political control throughout modern Syrian history. Under Ottoman rule, the aforementioned powerful urban families — all of whom were Sunni-functioned as the primary intermediaries between centrally appointed governors and the local population. The French Mandate (1920-1946) that followed essentially preserved this pattern of rule, with old urban classes continuing to monopolize an intermediary position similar to that which they had held for centuries under the Ottoman Empire (Khoury 1991, 1374). Members of the ethnically homogeneous urban intermediary class would dominate the legislative and executive branches through the early independence period, but would face demands from increasingly mobilized urban and rural masses organized on the basis of a shared peripheral identity, which crossed ethnic boundaries (Khoury 1991, p. 1393; Batatu, 1999, p.124-130).

The rural- and minority-dominated Ba'th Party seized power in a 1963 military coup and, in short order, nationalized most private industry and implemented sweeping land reform policies 
(Hinnebusch, 1989, p. 92). This coup cannot be understood as a simple takeover of the state by an ethnic group, however. The clandestine network in the Syrian Army that executed the coup was comprised of men from a range of ethnic backgrounds. Alawi officers would only emerge preeminent though a prolonged struggle following the coup (Batatu, 1999, p. 146). Precisely because there was no immediate ethnic solidarity between or established hierarchy among Alawi coconspirators in the inner circles of the $1960 \mathrm{~s} \mathrm{Ba}$ th regime, a struggle for leadership within the $\mathrm{Ba}^{\text {'t }}$ th ensued alongside the external struggle to reshape Syrian society (Seale, 1988, p. 150).

Hafez al-Asad, commander of the Air Force, emerged from this struggle victorious in 1970

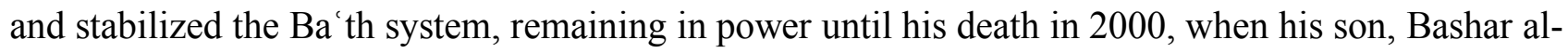
Asad, succeeded him. The guile of the older Asad played an important role in his ability to gain and hold power, but his direct outreach to local level Sunni leaders — of old urban classes and otherwise - played a major role as well. The economic strategy Asad adopted on seizing power relaxed the attack on private commerce and the (Sunni) urban classes transacting it. This change in policy was not lost on those who had borne the brunt of the radical Ba'th's attacks of the 1960s. On the news of al-Asad's capture of power, demonstrations broke out in Damascus and Aleppo, with merchants and artisans carrying banners reading, "We implored God for aid (al-madad). He sent us Hafez al-Asad!” (Batatu, 1999, p. 175).

The $\mathrm{Ba}$ th regime did face several episodes of mass challenge, including the Islamist uprising that culminated in a regime massacre in the city of Hama in 1982, killing between 5,000 and 20,000 (Seale, 1988, p. 326). Alongside this brutal repression by ethnically-dominated military and security forces, networks into various Sunni social groups played a critical role in checking the spread of rebellion. The regime used its ties to Damascene merchants to stop strikes that could have spread the uprising to the capital, in part by vastly increasing their import quotas (Seale, 1988, p. 327; Batatu, 1999, p. 208); called on network ties among local intermediaries in the periphery, such as tribal 
shaykhs in the city of Raqqa (Rabo, 1999, p. 181); and mobilized loyal tribes near Aleppo to police the desert for Muslim Brotherhood activity (Rae, 1999, p. 221).

Alongside repression and these targeted strategies of co-optation, the regime pursued a policy of redistribution in line with its official ideology of Arab Ba th Socialism, taking pains to improve the lives of many in the countryside, regardless of their ethnic identity. For example, it raised the number of villages with electrical power from 218 before 1970 to 5,729 in 1984 (Batatu, 1999, p. 66), and state marketing boards bought crops from cultivators at near-market prices and provided some measure of insulation from the volatility of world markets (Hinnebusch, 1989, p. 148).

A disaggregated picture of the relationship between ethnicity and state-provided goods underscores this point. Town-level data on ethnic identity, joined with census data (both described in section III), provide a picture of how goods were distributed on a mass level. Table 1 presents the distribution of public employment and public goods by ethnicity and town size. Three facts stand out. First, Alawis have far greater access to public employment than all other ethnic groups. If anything, these striking figures underestimate the extent of Alawi privilege in employment; the ethnicity measure used here captures only the majority identity of a town, and most of the largest cities are majority Sunni but feature a disproportionately high percentage of Alawis in their public sector employment rolls (Bishara, 2013, p. 321). Second, unlike public employment, public service provision evinces little ethnic bias; all towns have high levels of electricity provision and the lower levels of public water and sanitation found in Alawi, Sunni tribal, and Kurdish communities can be attributed to the tendency of these ethnic groups to live in rural areas, compared to non-tribal Sunnis. Finally, there is considerable variation in the levels of public employment among Sunni Arab towns. Even among homogeneously Sunni towns of a substantial size, there remained variation in levels of public employment; rates of state employment for the 136 Sunni Arab, non-tribal towns with over 10,000 residents ranged from 5 to 71 percent, with a mean of 30 percent and a standard deviation of 15 points. 
Table 1: Percent of population receiving state-provided goods, by town majority ethnicity and population size

\begin{tabular}{rcccc|cc}
\hline \hline & $\begin{array}{c}\text { public } \\
\text { employ. }\end{array}$ & water & electricity & sanitation & $\begin{array}{c}\text { number } \\
\text { of towns }\end{array}$ & $\begin{array}{c}\text { percent } \\
\text { total pop. }\end{array}$ \\
\hline by ethnicity & & & & & & \\
Sunni non-tribal & 29 & 94 & 98 & 85 & 1373 & 61 \\
Sunni tribal & 22 & 72 & 96 & 43 & 1646 & 19 \\
Alawi & 58 & 88 & 98 & 62 & 1104 & 9 \\
Kurd & 22 & 72 & 97 & 67 & 654 & 4 \\
Other minority & 41 & 91 & 98 & 73 & 427 & 7 \\
\hline by population & & & & & & \\
$>1$ million & 26 & 96 & 97 & 95 & 2 & 20 \\
100k to 1 million & 41 & 98 & 98 & 93 & 12 & 16 \\
$50 \mathrm{k}$ to 100k & 34 & 95 & 98 & 92 & 17 & 7 \\
10k to 50k & 29 & 93 & 98 & 81 & 168 & 19 \\
1k to 10k & 30 & 79 & 97 & 48 & 1941 & 29 \\
$<1 \mathrm{k}$ & 30 & 61 & 96 & 31 & 3064 & 8 \\
\hline \hline
\end{tabular}

Note: Ethnic identity and population percentages diverge from conventional estimates because ethnicity measures capture only the town majority identites; Sunnis are overcounted because major cities with ethnically-mixed populations, such as Damascus and Homs, are majority Sunni.

\section{Contemporary intermediary structures}

The picture of ethnic exclusion that emerges from this view of Syria is not one of whole ethnic groups with access to the state power and others totally excluded. Rather, intermediary networks connect local communities of all ethnic backgrounds to the ruling regime; high-ranking state officials and local informal leaders such as "clerics, tribal leaders, and wealthy people" link local populations to the central authority (al-Haj Saleh, 2017, p. 253-254).

Much of this informal access to the state was gained through extended family networks or by paying for it. Heavy-handed government restrictions on activities as simple as opening a small business or obtaining permission to travel abroad made informal access to the state highly valuable (Rae, 1999, p. 226). A state employee as lowly as the doorman at a local government office might be able to extract favors on behalf of a relative, or an acquaintance willing to pay him ${ }^{6}$ (interviews with

\footnotetext{
${ }^{6}$ The gender-exclusive pronoun is appropriate; the people monopolizing these positions were almost exclusively male.
} 
residents of Homs, Tripoli, June 14, 2014; Beirut, February 15, 2014). New terms for these relations entered the Syrian lexicon. Someone like the office manager (mudir maktab) of a senior ministry employee could be a "key (muftah)" because of how he could unlock access to state resources or permissions. An individual known for selling such access became known as a "gainer-granter (kassab wahhab)" (Bishara, 2013, p. 309).

Local tribal leaders constituted another major source of intermediary ties; whereas previous governments with greater ambitions for social engineering had sought to uproot all forms of tribal authority, Hafez al-Asad moderated the Ba'th Party's approach to the tribes upon assuming the Presidency. These arrangements were formalized with the appointment of many tribal leaders as the Parliamentary representatives for their localities (Batatu, 1999, p. 24). While such linkages may not have meant very many jobs or spoils being directed to average Syrians of tribal background, they gave local residents an intermediary through which to seek redress from the state when, for example, their relatives were arrested or they needed some sort of government permission (interview with Deir Hafir resident, Beirut, October 17, 2013; abd al-Rahman, 2016). Diesel smuggling, an outgrowth of heavy Ba'thist subsidization of basic goods, functioned as a more broad-based linkage for some local communities of tribal background. In 2008, smugglers in Syria could buy diesel for $\$ 0.14$ per liter and ferry it across the nearby border with Lebanon to sell it for $\$ 0.63$ per liter. This practice enmeshed many local communities in a complicated relationship with local security services, which had to be paid off for their acquiescence (Barout, 2012, p. 237).

In addition to these family relations, there existed a business elite with direct relations to the state. Though touching only a small population, primarily in central quarters of big cities, these ties entailed direct exchange with and compensation of state clients. The state-connected business elite grew primarily out of selective liberalization that began in 2000 following Bashar al-Asad's succession of his father as President of Syria (Barout, 2012, ch. 2). This elite, though focused mostly in Damascus and Aleppo, included many Sunnis. A magazine friendly to the regime published an 
article in 2010 celebrating 100 of the most prominent such businessmen; sixty-nine of these businessmen were Sunni Arabs (Bishara, 2013, p. 311).

The data on intermediary structures and state-provided goods suggest two faces to the $\mathrm{Ba}$ 'th social bargain. One face is the ethnically exclusive regime; Alawis occupy the highest positions of political power and are heavily favored in terms of state employment. The other face is an enervated modernizing socialist state. The historical Ba thist social contract sought to improve the lives of the rural masses, and its effects are visible in the relatively even provision of public goods across ethnic groups. In the absence of economic transformation, the regime cultivated patronage ties with local communities that regularly crossed ethnic lines. The presence of both forms of state access played a central role in the stability of the regime and in generating the widespread perception, among the Sunni majority, of ethnic favoritism. Local communities from all ethnic groups could be included or excluded on a network basis, but Alawi communities had, on average, far more access than any other ethnic group, and Sunni Arab communities comparatively less. These patterns laid the groundwork for fifty years of ethnically exclusive rule, and for the ways in which it would break down. The next section examines the modalities of this breakdown in 2011.

\section{QUANTITATIVE ANALYSIS OF MOBILIZATION}

This section introduces original data on Syrian town characteristics and contentious events in the first year of the Syrian uprising, then uses the new data to quantitatively test the state networks hypothesis against the rival hypotheses from the conflict literature. The claim advanced here is that challenge was overwhelmingly done by Sunni Arabs, but was attenuated within this group by local communities' linkages to the Syrian state. The fine-grained picture of contention these original data provide illustrates patterns of contention obscured by the higher levels of aggregation standard in the conflict literature and extant work on Syria.

The period under study runs from the outbreak of the initial demonstrations in February 2011 until the end of 2011. Challenger action over this period passed through three distinct phases: (1) 
peaceful popular protests aimed at reform and not the toppling of the regime (February - April 2011); (2) intensified, mostly non-violent protests calling for the fall of the regime, mixed with local residents carrying light weapons to demonstrations in order to deter regime attacks (May September 2011); and (3) full-scale civil war following widespread military defection and intensified violence (October - December 2011) (Bishara, 2013, p. 197-199). Though the regime met challengers with deadly violence from the onset of protests in some areas, the end of September 2011 marks an escalation of military repression and the formation of local militias loosely organized under the Free Syrian Army umbrella.

Data

The spatial unit of analysis is the Syrian Central Bureau of Statistics' community level census unit ( $\mathrm{n}=5204)$ referred to here as a 'town'. These settlements range in size from the country's capital and largest city (Damascus and Aleppo, respectively), each with over one million inhabitants, to hamlets consisting of several small farming settlements, with fewer than 1000 residents.

The ethnicity data were collected jointly with Kheder Khaddour (Khaddour and Mazur, 2016). We employed eight research assistants, who conducted 160 structured interviews with Syrians from all areas of the country to ascertain the ethnic composition of each town. Ethnicity coding was validated against maps compiled by local researchers and shared with the author, online sub-national maps, and online lists of village ethnic identity posted by local community members (see the online appendix for further detail). Because it is impossible to determine the exact percentages of two or more ethnic groups in a town, the empirical analysis uses only the majority identity of a town and whether or not a town's population was ethnically homogeneous.

A second new dataset tracks contentious events. It contains 2333 records of actions taken by the state, its challengers, and the state's allies in 2011. Events are counted at the level of the townday, with multi-day events coded as single events on their starting date. The dataset is based on multiple, diverse sources to minimize bias in event reporting. It draws on all relevant articles from 
the Associated Press, the daily digests of the Syrian Observatory for Human Rights, an oppositionleaning activist organization, and al-Thawra, the official political daily newspaper of the Syrian Ba'th Party.

The event database records three categories of actions - those taken by challengers, the regime, and allies of the regime. Challenger actions consist of non-violent protests and protests that begin non-violently, but turn violent in confrontation with state actors or regime allies. Events that begin as violence between challengers and the regime or its allies are coded as 'clashes'. Regime actions (other than clashes) are coded as 'crowd control' if they are directed at dispersing demonstrators without inflicting high levels of damage on protesters or monitoring them extensively; 'tactical control' if they entail an organized form of violence and surveillance directed at a specific segment of a city or town's population; and 'town destruction' if they target entire towns or major neighborhoods of large cities indiscriminately. Ally actions include demonstrations supporting the regime and unofficial militias or thugs, commonly called shabiha in Syria, harassing or fighting challengers (see al-Haj Saleh, 2017, ch. 2). Frequencies of each type of event in the database are displayed in table 2 .

Table 2: Count of ALL EVENTS in the 2011 Syrian uprising, by actor and type

\begin{tabular}{rcccc}
\hline \hline & Feb. - & May - & Oct. - & all \\
& Apr. & Sept. & Dec. & periods \\
\hline challenger & 178 & 658 & 137 & 973 \\
regime crowd control & 37 & 77 & 7 & 121 \\
regime tactical control & 35 & 338 & 244 & 617 \\
regime town destruction & 5 & 26 & 13 & 44 \\
ally & 57 & 226 & 168 & 451 \\
clash & 0 & 7 & 120 & 127 \\
\hline total & 312 & 1332 & 689 & 2333 \\
\hline
\end{tabular}

\section{Descriptive analysis of event data}

When the event data are paired with town ethnicity, two stark patterns emerge: first, nearly all contention occurs in Sunni locales and, second, many Sunni locales are not sites of contention. No 
homogeneously Alawi locale was the site of challenger action, and 97 percent of challenge events occurred in Sunni-majority locales; eighty-one percent of the demonstrations occurring in non-Sunni locales were either spillover of demonstrations from neighboring Sunni towns or actions spearheaded by members of the town's Sunni minority. In addition, no incidents of violent regime repression in non-Sunni towns appear in the database.

Many Alawis and members of other non-Sunni groups participated in demonstrations, but they did so overwhelmingly by moving out of their own neighborhoods or towns - individually or in small groups - to join demonstrations in Sunni towns and city centers, such as Homs and Damascus. The security presence and social opprobrium directed at any pro-uprising activity in the great majority of non-Sunni locales made holding demonstrations there impossible for local residents so inclined (Bishara, 2013, p. 142-4). As Rateb Shabo and co-authors (2015: 25) put it, "It is clear that Alawi participation in the revolution from the beginning was limited to an elite (musahema nukhbawiyya), and that where there was not Sunni mass movement, an Alawi opposed to the regime could find no place to be active, so the Alawi masses' distance from the revolution was clear from the beginning." Cities with significant Alawi and Sunni populations, like Lattakia, exemplify this dynamic. Lattakia was home to some of the first demonstrations in the uprising, but they occurred in central squares and the city's Sunni neighborhoods; Shabo et al. (2015: 11) note that the Alawis taking part were from an educated elite and drawn heavily from the ranks of the Communist Workers' Party and former political prisoners.

The obverse of minority quiescence — nearly uniform Sunni participation —was hardly the case. The most prominent examples of this phenomenon are the country's two largest and wealthiest (historically Sunni) cities, Damascus and Aleppo (Wedeen, 2013). Their quietism is borne out in the event data (see table 3); Damascus and Aleppo are the only two cities with over 1 million residents and account for far fewer of the demonstrations than their share of the population. Small- and medium-sized cities (with 10,000 to 100,000 residents) account for a disproportionate fraction of 
challenge events, particularly in the early months of the uprising; this latter group of cities has a combination of an educated, politically aware younger generation and high levels of exclusion from regime patronage networks, making them particularly contentious (Bishara, 2013, p. 157).

Table 3: Percent of total CHALLENGER ACTIONS in the 2011 Syrian uprising, by town charateristics

\begin{tabular}{rcccc|cc}
\hline \hline & $\begin{array}{c}\text { Feb. }- \\
\text { Apr. }\end{array}$ & $\begin{array}{c}\text { May - } \\
\text { Sept. }\end{array}$ & $\begin{array}{c}\text { Oct. } \\
\text { Dec. }\end{array}$ & $\begin{array}{c}\text { all } \\
\text { periods }\end{array}$ & $\begin{array}{c}\% \text { tot. } \\
\text { pop. }\end{array}$ & $\begin{array}{c}\text { number } \\
\text { of towns }\end{array}$ \\
\hline by ethnicity & & & & & & \\
Sunni non-tribal & 88 & 83 & 85 & 84 & 61 & 1373 \\
Sunni tribal & 6 & 9 & 7 & 8 & 19 & 1646 \\
Alawi & 1 & 0 & 1 & 1 & 9 & 1104 \\
Kurdish & 4 & 6 & 3 & 5 & 4 & 654 \\
Other minority & 1 & 2 & 4 & 2 & 7 & 427 \\
\hline total & 100 & 100 & 100 & 100 & 100 & \\
\hline \hline by population & & & & & & \\
$>1 \mathrm{MM}$ & 10 & 7 & 5 & 8 & 20 & 2 \\
100k to 1MM & 33 & 31 & 34 & 32 & 16 & 12 \\
$50 \mathrm{k}$ to 100k & 23 & 15 & 14 & 16 & 7 & 17 \\
10k to 50k & 33 & 41 & 34 & 39 & 19 & 168 \\
$1 \mathrm{k}$ to 10k & 2 & 6 & 12 & 6 & 29 & 1941 \\
$<1 \mathrm{k}$ & 0 & 0 & 1 & 0 & 8 & 3064 \\
\hline total & 100 & 100 & 100 & 100 & 100 & \\
\hline \hline
\end{tabular}

It would be unrealistic to expect that every Sunni town should be a site of contention-fear of repression, the absence of entrepreneurs to organize demonstrations, or simply small population size and isolation might account for a town's quiescence (Pearlman, 2016, p. 24). Yet fear and disorganization cannot explain the active role taken by many Sunnis in supporting the regime during the uprising, as the distribution of ally actions in the dataset makes clear. Of the 409 non-violent actions taken by state allies (non-state actors supporting the regime), 267 took place in Sunni majority towns. Seventy-one percent of these actions took place in governorate capitals with ethnically mixed populations, but this is not merely a function of minorities coming out in ethnically mixed locales; 18 percent of all ally actions occurred in homogeneously Sunni locales. 
Spatial units of analysis are an imperfect approximation of the identities and ties of individual actors engaging in challenge. Because revolutionary episodes are rare and unexpected occurrences, however, nationally representative survey data of this nature are rarely available and, even when available, can be subject to social desirability bias in respondents' self-description of participation (Beissinger, 2013). While spatial units of analysis do not allow for definitive pronouncements about the proportion of members of one ethnic group participating in challenge compared to another, the sites at which challenge occurs provide an approximation of the characteristics of groups engaging in contestation. They also offer clues about the social dynamics pushing individuals to demonstrate at one site or another; the paucity of demonstrations in non-Sunni locales, combined with qualitative evidence that non-Sunnis who wanted to demonstrate did so in urban centers and Sunni locales, suggests that non-Sunnis often faced enormous social pressure from their local communities against engaging in challenge.

Moreover, the town-level data presented here constitute an improvement on the spatial level of aggregation often used to study violent conflict in general — the country or sub-national regionand on Syria, in particular. Little can be said quantitatively about the role of ethnicity in the Syrian uprising based upon on extant data. No official statistics on exist on ethnicity, and even detailed maps (e.g., Izady, 2013) only gesture at the presence of ethnic groups in general regions rather than capturing the town-by-town variation necessary to understand the ethnic dimensions of contention. Work measuring ethnicity through the presence of an ethnic group at the administrative level above the town, the sub-district ( $\mathrm{n}=266$ ), has found ethnicity to have little role in structuring contention (De Juan and Bank, 2015). Though the town census unit also entails aggregation of some quite heterogeneous populations, pushing downwards from the sub-district constitutes a significant improvement in the resolution of the researcher's image of challenge and ethnicity in the Syrian uprising. 
Finally, the event data add important nuance to the picture of contentious challenge. Activistgathered databases of challenger deaths, such as the Violations Documentation Center (VDC) data (2016) and the Syria Tracker data employed by De Juan and Bank (2015), feature fine-grained spatial and temporal disaggregation. But death data fail to capture the dynamics of state-challenger interaction, particularly before state breakdown; seventy-nine percent of the challenge events in the database are non-violent, and of the 131 towns registering at least one challenge event, only 71 have any casualties recorded in the Syria Tracker database.

\section{Multivariable statistical analysis}

Before presenting the statistical analysis, this section sets out several alternate hypotheses and relates them to extant work on the Syrian uprising. While much of the literature on ethnic conflict makes predictions that do not account for intra-group variation, several strands do offer sub-ethnic group predictions. Weidmann (2011) finds that local ethnic diversity can cause competition between members of different ethnic groups, making conflict most intense in areas where diversity is highest. This hypothesis resonates with a line of argument about Syria, which holds that local ethnic geography—-specifically the presence of both Sunnis and Alawis in a town or a Sunni town being 'encircled' by Alawi villages - fueled ethnic competition and, eventually, violence (Balanche, 2011, p. 446; Hokayem, 2013, p. 45). The cross-national literature on civil war onset also offers predictions for patterns of intra-group variation in revolutionary participation. One line of thought, drawing on classic studies of peasant mobilization, sees material grievances as the central cause of revolutionary participation; on this view, the communities within a polity that suffer from the most acute deprivation should engage in challenge (ex. Boix, 2008). A complimentary explanation for the Syrian uprising highlights the marginalization of the Sunni "periphery," which is variously defined spatially, economically, and politically (Hokayem, 2013, p. 46; Droz-Vincent, 2014, p. 35). ${ }^{7}$ A

\footnotetext{
${ }^{7}$ The marginalization and local diversity explanations are not mutually exclusive - marginalization is unequally distributed across ethnic groups, and local conflicts among villages or neighborhoods
} 
second line in the cross-national literature sees ethnicity as an incidental correlate of conflict driven primarily by self-interested individuals seizing opportunities created by state weakness (Fearon \& Laitin 2003). On such a view, the areas where potential challengers face the lowest costs of action or stand to reap the greatest rewards should participate. Though this explanation has not been marshaled to explain the onset of challenge in Syria, state absence figured centrally in the entry of radical Islamist groups into Syria's east in 2013 (ain al-Madina 2015).

Several existing works on the Syrian uprising note the importance of state linkages, but lump them in with basic public goods provision or note them only in passing, relating their scarcity to other forms of marginalization (ex. Droz-Vincent, 2014, p. 35). Yet in basic public goods distribution in Syria followed a logic largely autonomous from the public employment and elite linkage strategies of the regime (see table 1). In separating these forms of linkage from basic public goods distribution and absolute levels of material deprivation, the present section facilitates adjudication between the state linkage hypothesis and its rivals.

To assess the determinants of intra-Sunni variation, this section employs a count model of challenger action. Because the challenge event data are overdispersed (the mean count of events per town is 0.2 and the variance is 6.0) a negative binomial model is employed to count challenge events, with the unit of analysis being the town over a given time period.

The state linkages hypothesized here to affect challenge come in two forms: public employment and patronage ties between the regime and local notables. To capture the first concept, Government worker measures the percentage of a town's workforce in public employment and is taken from the 2004 census. Informal ties between the regime and local communities cannot be captured as directly. Because the Syrian regime used the strategy of networking with local notables disproportionately among Sunni Arabs organized along tribal lines (Bishara, 2013, p. 218), a community having a tribal background serves as a proxy for this form of network between state and Moreover, the aforementioned works on Syria invoke both explanations to varying degrees. 
society. Tribes is a dummy variable drawn from the ethnicity database indicating that a town's population is of Sunni Arab tribal background. ${ }^{8}$

To evaluate marginalization hypotheses, the regression analysis includes the percentage of children enrolled in school (School enrollment) and the percentage of adults with secondary education or higher (Secondary school). ${ }^{9}$ To evaluate opportunity theories, it includes a dummy variable indicating presence of a major security or military facility in a town-sub district (Security base, drawn from expert ethnicity interviews) and a variable measuring a town's logged distance from the nearest provincial capital (Log(distance to capital)). Finally, to test the effect of local ethnic diversity on contention, a dummy variable indicating the presence of both Sunnis and Alawis in the same town $(A-S$ mix $)$ is included. Control variables are included for logged population size (Log(population)) and town population being majority Non-Sunni or Kurdish.

Table 4 fits this model on three subsets of the universe of Syrian towns: all towns, Sunnimajority towns only (which includes Kurds and Arabs), and Sunni Arab-majority towns only. The primary time period of interest is from the onset of initial demonstrations in February 2011 until civil war conditions began to prevail in October 2011 (specifications 1-3), though models are included for all of 2011 (4) and only the period of civil war (5). Specification 3, therefore, provides the most focused test of the hypotheses seeking to explain intra-Sunni variation, and its results are most consistent with the state networks hypothesis. Tribes has a strongly negative association with the

${ }^{8}$ Tribes is an indirect and imperfect measure of the intermediary relationship in question - not all tribal leaders were linked to the regime, and many communities whose members do not describe themselves in a tribal idiom have dense social ties and solidarities common to communities of tribal background. Additionally, many rural populations that have been sedentarized for generations and no longer describe themselves in a tribal idiom place high value on kinship ties, and some tribal leaders have long been ambivalent towards or opposed to the regime (Barout, 2012, p. 146, 262-269). In general, however, the 'tribal' coding captures the heightened propensity for a local community to have dense network ties among their members and be linked to the regime through clan-based intermediaries (see also Batatu, 1999, p. 22-29).

${ }^{9}$ Basic public goods, like electricity and water, could theoretically offer another indicator of a town's marginalization. In the Syrian context, however, successful state efforts to provide these resources to all communities mean that these variables do not differentiate levels of development or say much about community access to state resources. See the appendix for alternate specifications including these variables. 
level of challenge, and Government worker is also negatively associated with levels of challenge for the time period.

Table 4: Negative binomial regression of challenge events on town characteristics

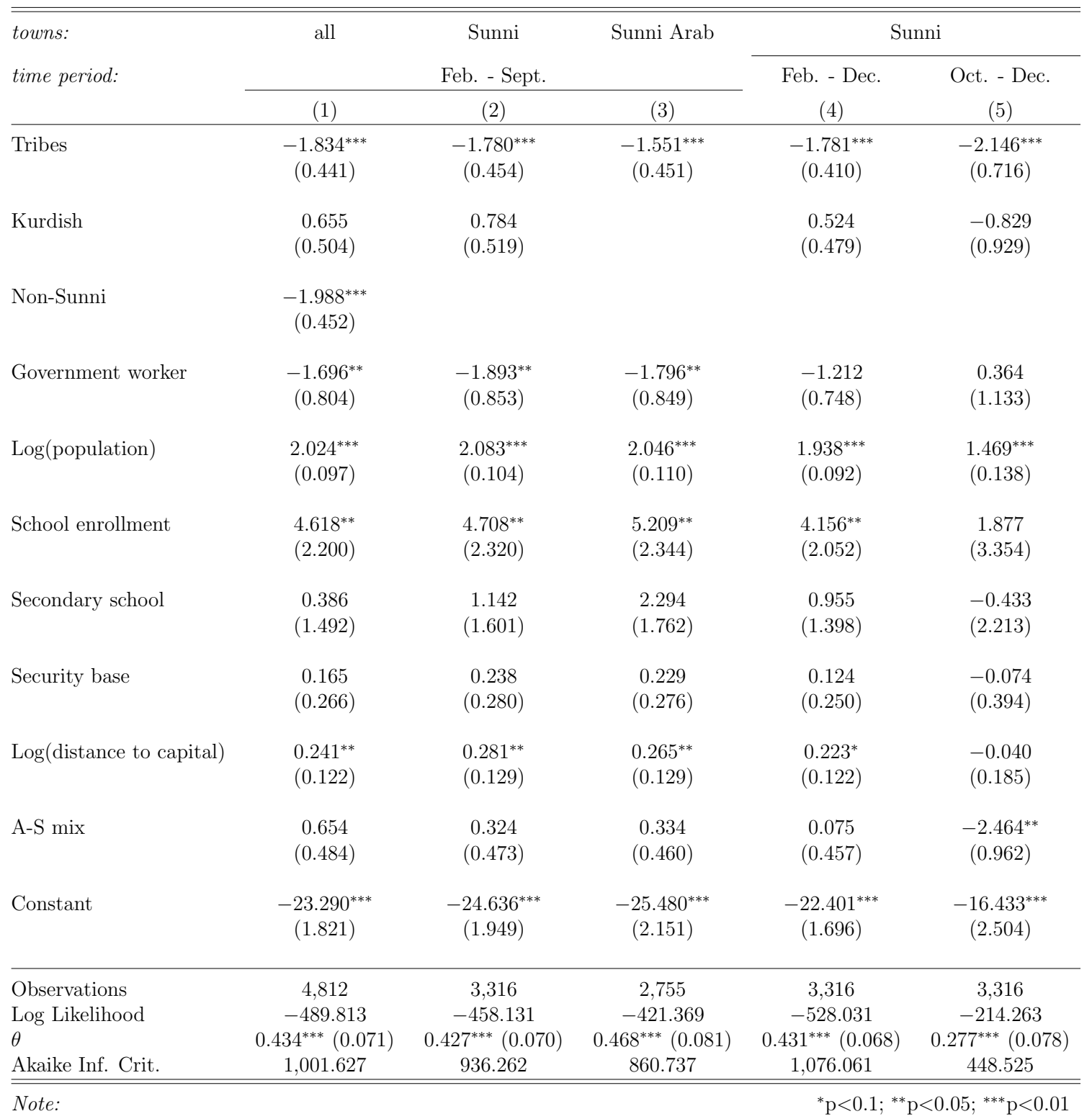

The alternate hypotheses find less support in the multivariable analysis. The variables predicted to be associated with challenge by material grievance theories are either not statistically significant (Secondary school) or signed in the wrong direction (School enrollment). The opportunity hypothesis finds limited support, as well. While distance from governorate capitals (Log(distance to capital)) is associated with an increased propensity for challenge, Security base is signed in the 
wrong direction for the opportunity hypothesis and has no statistically significant association. This suggests that the state linkages of regime-favored communities in city centers, rather than presence of security forces, may better account for the positive statistical association of distance from capitals and contention. Finally, local ethnic heterogeneity $(A-S$ mix $)$ is not statistically associated with challenge, casting doubt on the diversity hypothesis. Alternate operationalizations of the rival hypotheses - such as Alawi encirclement of Sunni towns as an indicator of local diversity, unemployment and illiteracy as indicators of marginalization, and terrain ruggedness as indicator of opportunity - are examined in the appendix; the results are substantively the same as those in Table 4.

Specifications 4 and 5 expand the time period over which events are counted to the end of 2011; while Tribes continues to be a statistically significant and negative predictor of the frequency of challenge, Government worker ceases to have a statistically significant association with challenge. This is consistent with work on the micro-dynamics of civil wars demonstrating that, once state authority is absent, pre-existing structural factors exert a less powerful role than dynamics emerging during the course of conflict.

The coefficient of Kurdish is positive but not statistically significant for the pre-civil war period (specifications 1 and 2), suggesting that Kurdish communities acted in ways similar to Sunni Arab communities in the period under study. Kurds faced harsh cultural discrimination and economic neglect by the Syrian regime, causing many Kurdish towns to engage in non-violent contention for the same reasons as their Arab counterparts during the first months of the uprising. The switch in the sign of Kurdish in late 2011 (specification 5), although not statistically significant, presages a significant change; regime conciliation with key Kurdish intermediaries as the uprising became increasingly violent in 2012 would largely hive Kurdish communities off from the broader uprising. Though a number of factors are at play in this development, including civil war violence 
and missteps by the Arab opposition, the relations between the regime and Kurdish actors who could mobilize or control local society played a central role (Allsopp, 2014, p. 197-216).

Finally, a concern about endogeneity merits mention. If the regime only forged links with towns that were less likely to challenge it in the first place, pre-existing social features would be unobserved variables driving challenge that appears to be impelled by a lack of state ties. The history of ruling coalition formation, however, suggests that this fear is unfounded. Nearly fifty years of $\mathrm{Ba}$ 'th rule gave the regime considerable latitude to structure its coalition partners. In fact, the regime ultimately forged ties with groups historically opposed to central authority — and to the Ba 'th itselfand with the highest levels of capacity to challenge it. Communities of tribal background arguably had the highest capacity to engage in violent confrontation with the regime, as they were never fully disarmed and the regime allowed them substantial autonomy. Yet their relations with the regime led to, on average, lower levels of challenge in the 2011 uprising. In addition, many of the areas that were most hostile to the radical Ba'th regimes of the $1960 \mathrm{~s}$ - including the urban centers of Damascus and Aleppo — were drawn into its orbit through patronage, particularly following the economic opening of 2000 (Khaddour, 2017, p. 8-9). The modalities through which state linkages to Sunni communities constrained challenge are examined in the next section.

\section{MECHANISMS}

The statistical analysis demonstrates that state employment and local notables' connections to the Syrian regime attenuated the frequency of challenge in Sunni locales during the 2011 uprising. Yet these two forms of state linkage operated in quite different ways. State employment enabled the regime to coerce employees into quiescence through the threat of withdrawal of individual benefits related to their employment. Ties between the regime and tribal notables, by contrast, promoted quiescence because notables could command the obedience of densely linked local communities they represented (though not entirely, as the discussion below suggests). 
Were depth of material grievance or remoteness from coercive state authority the primary factors impelling challenge, communities with tribal social structure should have been among the earliest and most forceful participants in the uprising; they are concentrated primarily in the country's peripheral eastern areas and, in general, have lower levels of state employment and socioeconomic development than the rest of the country. Yet these factors were overcome by the structures in which individuals of tribal background found themselves: namely, local communities with dense network ties and leaders linked to the regime. The city of Raqqa exemplifies this dynamic. This remote eastern city's residents are almost all Sunni Arabs and the city had the lowest secondary school enrollment and adult literacy rates of all governorate capitals (Central Bureau of Statistics, 2004); nearly all residents were members of a clan or extended kinship network (Rabo, 1999, p. 176). In the decades preceding the uprising, the regime often declined to involve itself in the daily affairs of residents of Raqqa, frequently leaving clan leaders to sort out disputes among local residents, and even to adjudicate serious crimes. A saying common to the Raqqa area captures this state approach towards notables: "give loyalty and do as you please ( $i$ 'ti wala' w-ifa 'l ma tasha')" (interview with Deir Hafir resident, Beirut, October 17, 2013). Long-standing state-notable linkages were strengthened following the US invasion of Iraq in 2003, as the regime increased the admission of Raqqa clan leaders' sons into the military (Bishara, 2013, p. 218).

These features of Raqqawi society made it possible, and rational, for local notables with longstanding relations to the regime to enjoin members of their extended family, clan, or neighborhood not to participate in demonstrations. To a great extent, this command was heeded; Raqqa saw no major demonstrations against the regime in the first year of the uprising. Youth activists of the city organized clandestine Local Coordinating Committees and sought, in mid-2011, to organize demonstrations against the regime, just as activists were doing at that time throughout the country. But they were commanded by the city's tribal notables not to assemble in the central square, and largely followed those orders. Demonstrators limited their activity to nighttime "flying 
demonstrations" (tadhahourat tayyara), where small groups met in central locations for less than a half hour and dispersed before authorities arrived (abd al-Hay 2012); these demonstrations were so short that they were hardly covered in the media and do not appear in the event database.

To shore up these ties, in November 2011 (while swathes of the country were already falling into sustained violence), President Bashar al-Asad visited Raqqa to celebrate an important Islamic holiday - Eid al-Adha. He prayed at the central mosque ${ }^{10}$ and met with local notables, emerging from these meetings to be greeted by a cheering crowd of thousands in the city's central square. During this trip, the President proclaimed that the tribes "were always the national repository of the traditions and authentic stances" of the Syrian people (SANA 2011).

Actions of the local notables, who sought to preserve their intermediary position and the benefits of office and patronage that accompany it, are easily explicable in terms of short-term pursuit of individual interest. Yet a more complicated calculation is necessary to account for the compliance of members of the local communities under their sway, who lacked such direct patronage ties to the regime and were largely excluded from the spoils of state employment. Their obedience can best be explained in terms of their network, whether because of material returns to its maintenance or due to its value as a community as such. ${ }^{11}$ Members of the local community depended on local leaders for vague future benefits - such as intervention with regime officials to get a relative out of jail or papers to travel abroad—-from which disobedience in the moment would exclude them. Moreover, many of the non-state resources local residents hoped to access, like jobs driving trucks in the Gulf states, could only be obtained through one's extended family ties.

\footnotetext{
${ }^{10}$ The mosque, and nearly all Raqqa residents, were Sunni, underscoring the regime's efforts to retain ties across ethnic lines; in attending this mosque with the highest-ranking Sunni clerics in the country (Mufti Ahmed Hassoun and Minister of Religious Foundations Muhammad Abdel Sattar alSayyed), al-Asad was following a longstanding regime policy of the (Alawi) President publicly practicing Islam in a Sunni idiom (see Pierret, 2013, p. 21).

${ }^{11}$ Though she describes it in "ideological" rather than network terms, Lisa Wedeen $(2013$, p. 847) advances a parallel argument, noting that many members of Syrian communities with this form of social ties forsake individual material benefits they could gain from state networks because the latter would undermine their community and way of life.
} 
Participation in the uprising in defiance of members of this network would endanger access to those resources, as well.

State employment constituted an additional network through which the Syrian regime could coerce the population into quiescence, but it worked through primarily individual mechanisms. Some state employees may have remained at home when anti-regime protests began out of a sense of attachment to the state and, by extension, the political regime. But state employment also constituted a tool through which the regime could coerce its more ambivalent subjects into obedience during the uprising. Fear of losing one's livelihood acted as a selective dis-incentive to participation; the Syrian regime played on this fear by regularly video recording demonstrations to identify participants and firing state employees who took part (Dhaher, 2013, p. 8; interview with Damascene activist, Beirut, April 9, 2014; Hokayem, 2013, p. 49). Moreover, the regime bused state employees from their places of work to pro-regime demonstrations (Shadid, 2011). These actions follow a well-honed technique of using state institutions as a lever to ensure compliance; the regime regularly bused employees from work to polling stations for Presidential referenda, helping to produce the over 98 percent margins of approval and over 95 percent turnout in these 'elections' for decades. In the 2014 Presidential referendum, for example, the regime even compelled employees to bring family members to polling stations (al-Faysal, 2014, p. 5).

The effect of state linkage as a tool of coercion is visible in patterns of contestation in the capital, Damascus. The city center is home to a wealthy, regime-connected elite that includes many Sunni businessmen. While many suburbs of Damascus erupted in protest and, eventually, violence, the city center remained almost entirely free of anti-regime demonstrations. This quiescence has been put down to regime clients' fear of what they would lose were the regime to collapse (or, were it not to collapse, to have been seen defying it), in addition to the heavy security presence in the center (Bishara, 2013, p. 173). 
Even in more modest quarters, populated by mere state employees and outside the heavy security presence of the city center, the effects of state networks can be observed. Many neighborhoods of present-day Damascus are old orchard towns that have been swallowed by the city in recent decades and, as the city surrounded these former towns, vastly different communities came to live alongside one another. Next to the old orchard town of Barzeh al-Balad, the state built a housing block intended for and inhabited mostly by government employees called Masakin Barzeh (“Barzeh Housing”). A spontaneous, informal settlement called 'ash al-Warwar-inhabited primarily by Alawis coming to the city to work in state institutions or the military — arose next to these two settlements. Residents of Barzeh al-Balad worked primarily in independent trade and small industry, rather than state employment (placing them in the 'doubly excluded' quadrant of figure 1). They also exhibited dense intra-group social ties and sparse ties to outsiders typical of a small, relatively insular community. One interview subject of generational Barzeh al-Balad provenance recalled being called the "son of the Alawi woman (ibn al-'Alawiya)" because his mother was from an elite (Sunni) Damascene family and did not cover her hair when going out on the street in Barzeh (interview, Beirut, April 9, 2014). Rather than pure ethnic bias (though this surely played a part), the remark indicates the insularity of the local Barzeh al-Balad community; a woman who comes from outside the community and refuses to conform to its norms is as much a stranger as the ostensible ethnic other.

Demonstrations broke out in Barzeh al-Balad within weeks of the first demonstrations in Syria, and local solidarity played a key role in impelling and sustaining participation there. The same interview subject noted that a common reason given for participation was to "defend our blood [relations]," that is, because extended family members had been harmed and insulted by the regime. State agents, alongside thugs from neighboring 'ash al-Warwar, repressed demonstrations (Ismail 2013, p. 883). Protests in Barzeh al-Balad and other peripheral areas of Damascus continued despite this repression because their residents were ready to endure violent repression that wealthy 
individuals from the center of the city were not (Pierret, 2013, p. 232). Far less contentious activity occurred in Masakin Barzeh, even though the majority of its inhabitants are also Sunnis. ${ }^{12}$

These examples suggest the multivalence of dense local network ties in the Syrian uprising. Whereas individuals without such dense social ties to their community but strong ties to the regime, like state employees, could be coerced not to protest based upon what they stood to lose as individuals, the calculations of an individual Sunni person in a densely linked community could weigh in either direction; dense networks at the clan or village level allowed the regime to stave off protest in many areas of Syria's east, but dense network linkages were also central to challengers' overcoming collective action problems. ${ }^{13}$ The factor that inclined some communities with such ties away from contestation was the connection of the community to the regime through an intermediary. Yet even tribal ties eventually failed to ensure compliance; as state control broke down and prolonged regime-challenger clashes erupted increasingly in late 2011 and 2012, the regime began to use violence against members of communities that had been linked to it through intermediaries, causing the solidarity that formerly held off demonstrations to turn entire communities against the regime. In Raqqa, for example, local youth activists finally disobeyed local tribal notables in March 2012, organizing a demonstration in the central square to mark the one-year anniversary of the first demonstration in Syria. State efforts to restrain protesters pulling down a statue of Hafez al-Asad killed several community members, leading to a 100,000-person demonstration that Azmi Bishara (2013, p. 219) estimates to be the largest demonstration in Syria during 2012.

Understanding the role of local community structures and network linkages in Sunni communities sheds new light on patterns of quiescence among non-Sunni communities, as well. The

\footnotetext{
${ }^{12}$ Statistical disaggregation of the Barzeh case is not possible because all of these neighborhoods fall within the same administrative unit, Damascus city. The clearest quantitative view of this area, therefore, comes from the VDC (2016) data, which record the place of origin for all individuals killed by the regime in the uprising, down to the neighborhood level. Twenty natives of Barzeh alBalad were killed in the period before civil war, compared with zero in both Masakin Barzeh and 'ash al-Warwar.

${ }^{13}$ Exemplary work on this phenomenon has been done for Dar'a (Leenders, 2012) and the periphery of Aleppo (Khaddour, 2017).
} 
data on public employment and ethnicity suggest that the ethnically included non-client group in Syria is a small one, particularly in comparison to the doubly excluded Sunni group. Moreover, senior Alawi and other minority government officials could act as intermediaries to their local communities, intervening on community members' behalf and monitoring them for the regime. Fear undoubtedly played a role in the quiescence of minority communities, but this fear was not solely of a Sunni-dominated regime; the potential loss of the material benefits of state linkage provided motivation not to protest and gave the regime leverage, just as it did for Sunni clients. The fact that members of non-Sunni ethnic groups did try to protest suggests that fear of Sunni domination was distributed unevenly across minority populations. The modalities by which minority demonstrations were squelched suggest important mechanisms inclining minorities towards quiescence. Recall that that youths in Alawi neighborhoods and villages who wanted to protest went to the center of Sunnimajority cities. To do so, they carried banners as 'delegations' from Alawi locales because of the enormous social sanction they would have faced from relatives and neighbors had they attempted demonstrations in their home locality (Bishara, 2013, p. 142-3). The combination of dense local ties and regime-connected intermediaries provided powerful incentives to local communities to suppress their youths' attempts at protest.

\section{CONCLUSION}

This article suggests that networks providing local communities access to central state resources frequently cross ethnic lines, and that these ties best explain intra-ethnic group variation in patterns of revolutionary challenge. Theories of ethnic identity and intrastate violence in the crossnational literature have rightly emphasized the role of exclusion from access to central power in impelling challenge. But the assumption that access to or exclusion from state power is allotted to entire ethnic groups covers up intra-ethnic group variation crucial to understanding the means by which grievances are channeled into revolutionary challenge. 
By disaggregating the events of the 2011 Syrian uprising using town-level event data, this article reveals patterns unobservable in ethnic group or administrative district-level aggregates. These patterns simultaneously reinforce the commonly held notion that contention in Syria was patterned on ethnic lines and raise questions about the sufficiency of 'ethnic' exclusion as an explanation for revolutionary challenge. On the one hand, contention had a clear ethnic structure; members of non-Sunni ethnic groups participated only as individuals or small collectives, traveling to Sunni towns or the centers of Sunni majority cities to protest. On the other hand, many Sunni towns did not engage in contention, and many Sunnis even turned out on the street to show their support for the regime. In other words, grievances held disproportionately by Sunnis generated mobilization, but they did so unevenly across the individuals and local communities of this ethnic identity. The primary factor differentiating Sunnis who engaged in challenge from those who counter-mobilized to support the regime or simply remained on the sidelines was inclusion in the regime's networks. Not all of these networks operated in the same fashion, however; ties between the state and government employees created individual material incentives against participation, while intermediary ties to communities with dense family, clan, and tribal ties compelled quiescence among local populations that often received few of the spoils dispensed by the regime to their patron.

In relating patterns of Sunni challenge to pre-existing network structures, this article also sheds light on the ways in which the Alawi-dominated Ba th regime ruled over a Sunni majority population for decades. Alawi communities had network access to state-controlled resources at far higher rates than all other communities, but many local communities with 'excluded' ethnic identities also enjoyed a considerable degree of access. The benefits dispersed through these tiesand the leverage the intermediaries dispensing those benefits exerted on behalf of the regime — made a significant segment of the excluded ethnic group compliant with, if not invested in, the Ba thist status quo. 
By loosening the assumption that ethnic group and network boundaries are coterminous, this article invites further, cross-regional research on the structure of network ties and ethnic identity. Legacies of Ottoman rule and the struggle of a multi-ethnic, rurally-dominated military against old landed classes weighed heavily on the political arrangement of post-independence Syria. This statesociety relationship stands in marked contrast to the compact between 'Big Man' ethnic elites federating a state of separate ethnic groups found in the ethnic powersharing literature. Ascertaining which of these models is more common across other world regions will have important implications for how scholars should understand intrastate violent conflict unfolding primarily along ethnic lines. 


\section{REFERENCES}

abd al-Hay, T. (2012, April 6). al-Raqqa: al-'asha'ir tahsum al-mawqif [Raqqa: the Tribes Decide their Position]. Al-Akhbar. Retrieved from http://www.al-akhbar.com/node/61762

abd al-Rahman, S. (2016, September 19). Mayadin al-furat al-rahba [Mayadin of the Euphrates and al-Rahba]. Al-Jumhuriya. Retrieved from https://www.aljumhuriya.net/ar/35532, https://www.aljumhuriya.net/ar/35563

ain al-Madina. (2015). The Oil of Deirezzor: From the Revolution to ISIS. Deir az-Zor, Syria. Retrieved from http://www.3ayn-almadina.com/?wpdmdl=6514

al-Faysal, H. (2014, June 16). Li-matha intakhab Sa'id Bashar al-Asad?! [Why did Sa'id vote for Bashar al-Asad?!]. 'Ain Al-Madina, (30), 5.

al-Haj Saleh, Y. (2017). The Impossible Revolution. London: Hurst.

Allsopp, H. (2014). Kurds of Syria. London: I B Tauris.

Balanche, F. (2011). Géographie de la révolte syrienne. Outre-Terre, 29(3), 437-458.

Baldwin, K. (2016). The paradox of traditional chiefs in democratic Africa. New York: Cambridge University Press.

Baram, A. (1997). Neo-Tribalism in Iraq: Saddam Hussein's Tribal Policies 1991-96. International Journal of Middle East Studies, 29(01), 1-31.

Barout, M. J. (2012). al-'Aqd al-akhir fi tarikh souriya: jadaliyyat al-jumud wal-islah [The last decade in Syria's history: dialectic of stagnation and reform]. Beirut: al-Markaz al-'Arabi lilAbhath wa-Dirasat al-Siyasat.

Batatu, H. (1999). Syria's Peasantry, the Descendants of Its Lesser Rural Notables, and Their Politics. Princeton: Princeton University Press.

Beissinger, M. R. (2013). The Semblance of Democratic Revolution: Coalitions in Ukraine's Orange Revolution. American Political Science Review, 107(3), 1-19.

Bishara, A. (2013). Suriyah, darb al-alam nahwa al-hurriyah: muhawalah fi al-tarikh al-rahin [Syria, a path to freedom from suffering: an attempt in contemporary history]. Beirut: alMarkaz al-'Arabi lil-Abhath wa-Dirasat al-Siyasat.

Boix, C. (2008). Economic Roots of Civil Wars and Revolutions in the Contemporary World. World Politics, 60(3), 390-437.

Brubaker, R. (2015). Religious Dimensions of Political Conflict and Violence. Sociological Theory, $33(1), 1-19$.

Central Bureau of Statistics, S. (2004). 2004 National Census. Retrieved from http://www.cbssyr.org/indicator/hp-f.htm

Coleman, J. S. (1988). Social Capital in the Creation of Human Capital. American Journal of Sociology, 94(Supplement), S95-S120. 
Courbage, Y. (2007). La population de la Syrie: des reeticences à la transition (demographique). In B. Dupret, Z. Ghazzal, Y. Courbage, \& M. al-Dbiyat (Eds.), La Syrie au présent: reflets d'une société (pp. 177-214). Paris: Actes sud.

Corstange, D. (2016). The price of a vote in the Middle East: clientelism and communal politics in Lebanon and Yemen. Cambridge: Cambridge University Press.

De Juan, A., \& Bank, A. (2015). The Ba'athist blackout? Selective goods provision and political violence in the Syrian civil war. Journal of Peace Research, 52(1), 91-104.

Dhaher, O. (2013, August 1). Furus al-'amal al-jadid? [New work opportunities?]. 'Ain Al-Madina, (9), 8.

Droz-Vincent, P. (2014). "State of Barbary" (Take Two): From the Arab Spring to the Return of Violence in Syria. The Middle East Journal, 68(1), 33-58.

Fearon, J. D., \& Laitin, D. D. (2003). Ethnicity, insurgency, and civil war. American Political Science Review, 97(1), 75-90.

Habyarimana, J., Humphreys, M., Posner, D. N., \& Weinstein, J. M. (2009). Coethnicity: Diversity and the Dilemmas of Collective Action. New York: Russell Sage Foundation.

Hinnebusch, R. A. (1989). Peasant and Bureaucracy in Bathist Syria: The Political Economy of Rural Development. Boulder: Westview Press.

Hokayem, E. (2013). Syria's Uprising and the Fracturing of the Levant. Abingdon: Routledge.

Ismail, S. (2013). Urban Subalterns in the Arab Revolutions: Cairo and Damascus in Comparative Perspective. Comparative Studies in Society and History, 55(4), 865-894.

Izady, M. (2013). Syria Ethnic Composition (Detailed). Gulf/2000 Project, Columbia University. Retrieved from http://gulf2000.columbia.edu/maps.shtml

Kalyvas, S. N. (2006). The Logic of Violence in Civil War. New York: Cambridge University Press.

Khaddour, K. (2017). Consumed by War: The End of Aleppo and Northern Syria's Political Order. Friedrich Ebert Stiftung. Retrieved from http://library.fes.de/pdf-files/iez/13783.pdf

Khaddour, K., \& Mazur, K. (2016). Syria Town Ethnicity Database. [Data set].

Khoury, P. S. (1991). Continuity and Change in Syrian Political Life: The Nineteenth and Twentieth Centuries. The American Historical Review, 96(5), 1374-1395.

Koter, D. (2016). Beyond ethnic politics in Africa. New York: Cambridge University Press.

Leenders, R. (2012). Collective Action and Mobilization in Dar'a: An Anatomy of the Onset of Syria's Popular Uprising. Mobilization: An International Quarterly, 17(4), 419-434.

Lyall, J. (2010). Are Coethnics More Effective Counterinsurgents? Evidence from the Second Chechen War. American Political Science Review, 104(1), 1-20.

Pearlman, W. (2016). Narratives of Fear in Syria. Perspectives on Politics, 14(1), 21-37. 
Pierret, T. (2013). Religion and state in Syria: the Sunni Ulama from coup to revolution. New York: Cambridge University Press.

Rabo, A. (1999). Faith and Identity in Northeast Syria. In L. O. Manger (Ed.), Muslim diversity: local Islam in global contexts (pp. 173-199). Surrey: Curzon.

Rae, J. (1999). Tribe and State: Management of the Syrian Steppe. PhD dissertation, University of Oxford.

Roessler, P. (2016). Ethnic politics and state power in Africa: the logic of the coup-civil war trap. Cambridge: Cambridge University Press.

SANA. (2011, November 6). al-Ra'is al-asad yu'di salat "eid al-adha al-mubarak fi jami" al-nour bilRaqqa [President Asad Leads Prayers for Blessed Eid al-Adha in al-Nour Mosque in Raqqa]. Retrieved January 22, 2015, from http://www.discover-syria.com/news/12740

Seale, P. (1988). Asad of Syria: The Struggle for the Middle East. London: I.B. Taurus.

Shabo, R., Bissan, W., Ali, Z., \& Ja'far, N. (2015). al-'Alawiun wal-thawra al-souriya [The Alawis and the Syrian revolution] Democratic Republic Studies Center. Retrieved from http://drscsy.org/wp-content/uploads/2015/11/rateb1.pdf

Shadid, A. (2011, June 21). Syrians Rally, This Time in Support of Assad. The New York Times. Retrieved from http://www.nytimes.com/2011/06/22/world/middleeast/22syria.html

Tilly, C. (1973). Does Modernization Breed Revolution? Comparative Politics, 5(3), 425-447.

Violations Documentation Center in Syria. (2016). Martyrs database. Retrieved from http://vdcsy.net/en/

Wedeen, L. (2013). Ideology and Humor in Dark Times: Notes from Syria. Critical Inquiry, 39(4), 841-873.

Weidmann, N. B. (2011). Violence "from above" or "from below"? The Role of Ethnicity in Bosnia’s Civil War. The Journal of Politics, 73(4), 1178-1190.

Wimmer, A. (2013). Ethnic boundary making: institutions, power, networks. New York: Oxford University Press.

Wimmer, A., Cederman, L.-E., \& Min, B. (2009). Ethnic politics and armed conflict: a configurational analysis of a new global data set. American Sociological Review, 74(2), 316337. 
DATA APPENDIX FOR "STATE NETWORKS AND INTRA-ETHNIC GROUP VARIATION IN THE 2011 SYRIAN UPRISING," COMPARATIVE POLITICAL STUDIES

\author{
KEVIN MAZUR
}

kevin.a.mazur@gmail.com

\title{
I. EVENT CODING
}

The event data record nine types of actions, coded on a scheme developed inductively from descriptions of events in secondary sources, the newspaper articles themselves, and author interviews with participants and Syrian observers of the uprising. Actions are divided by actor: challenger, regime, regime ally.

Regime actions are as follow:

(1) incumbent crowd control. This tactic captures actions directed at dispersing demonstrators without inflicting high levels of damage on protesters or monitoring them extensively. This category encompasses actions of far more force than one might expect of crowd control in an industrialized democracy. It includes: barricading, non-violently dispersing protests and arresting demonstrators, tear gassing and beating demonstrators, and firing into the air (when doing so causes fewer than two casualties).

(2) tactical control. This tactic involves an organized form of violence and surveillance directed at a specific segment of a city or town's population, but not the whole town or major neighborhood of a large city. These tactics appear to be geared at separating a contentious population from the rest of the town/city or punishing a specific subset of the city's residents. Examples include: raiding a neighborhood to make arrests, encircling a neighborhood and cutting power and water for several days, storming a neighborhood, opening fire randomly on demonstrations, and using snipers to kill people out demonstrating on the street.

(3) town destruction. These events target entire towns or major neighborhoods of large cities indiscriminately. They inflict heavy damage, either mass property destruction or the killing of 20 or more people. Actions in this category include the siege of entire cities, the shelling of a neighborhood, and the burning of homes.

(4) confront. This tactic describes security or military forces clashing with armed opposition fighters, including formal battles between armed units, skirmishes with defectors, and attacks following an ambush.

Distinctions among the three challenger actions are:

(1) non-violent action, in which a group gathered to make demands on the regime and no violent action was reported;

(2) spontaneous violent action, where crowds initially amassed to demonstrate non-violently and shifted towards the use of violence, such as throwing rocks or beating state allies;

(3) coordinated violent action, involving groups such as "rebels" or "defectors" engaging in coordinated attacks on state forces (the compliment of regime "confront" actions).

Allies are any actors without an official affiliation to the state that act to support the incumbent or harm its challengers. They can take two sorts of actions in the coding scheme: (1) violent action or (2) non-violent action. When gathered to voice support the state, whether as a counter demonstration or on its own, ally actions count as non-violent. Any sustained physical attack - from throwing stones at and using knives against anti-incumbent demonstrators to organized militias destroying villages supporting challengers - counts as ally violent action. 


\section{EVENT DATABASE}

The event database, collected on the period from February 2011 through August 2012 contains 4424 observations, though only events through December 2011 are analyzed in this article. It follows the structure of Charles Tilly's (1995) dataset on contention in nineteenth-century Great Britain, recording a set of subject-verb-object sequences for actions taken by the state, its challengers and the state's allies. These strings were subsequently fit into the typology described above.

Newspaper-based event data have come under criticism for ignoring events in small and remote locales (selection bias) and for misrepresenting those events they do report (veracity bias) due to the agenda of the newspaper (Ortiz et al., 2005; Weidmann, 2015). Using multiple sources with conflicting agendas helps to addresses veracity bias, as the opposed political agendas of alThawra and the Syrian Observatory for Human Rights make it highly unlikely that both would miss covering a major event unflattering to the other camp. Using multiple sources required the author to make coding decisions sometimes based upon explicitly contradictory reports. These decisions involved rejecting obvious government fabrications (e.g. when the government shelled the center of Homs, al-Thawra claimed that "terrorists are using smoke bombs to make it look like the government is shelling the city center"). In such situations, I consulted of third-party reports, including the scholarly monographs of Jamal Barout (2012) and Azmi Bishara (2013) and the reports of international organizations like Human Rights Watch and Amnesty International. In addition, the coding of events was done in view of all relevant reports to place all potential source biases in view and prevent double-counting of events (Weidmann \& Rød, 2015).

There is undoubtedly underreporting of events in small, peripheral locales, but the use of local newspapers makes this far less likely than in datasets based upon major international papers or machine-coding. Whereas the original database (through December 31, 2011) records 2333 events in 436 towns, one leading machine-coded database, GDELT, has observations in 13973 total observations in 97 Syrian towns (Leetaru \& Schrodt, 2013; coding rules for transforming this database to the scheme employed here available in replication files). For challenge events in the first year of the uprising - the outcome variable in the present study - the author's database records 973 events in 134 towns, compared to 164 in 32 towns in GDELT; whereas the five towns with the most observations are the site of 30 percent of all observations in the author database, the top five towns account for 57 percent of observations in GDELT. Figure A1 depicts the difference. Finally, selection bias in event recording is also less of a worry when trying to understand the types and sequencing of contention across locales, what Tilly (2002) calls their "internal regularities," than in studies focused on the initial onset of events in a locale. 
Figure A1: Comparison of coverage across databases

(a) original database $(n=2333)$

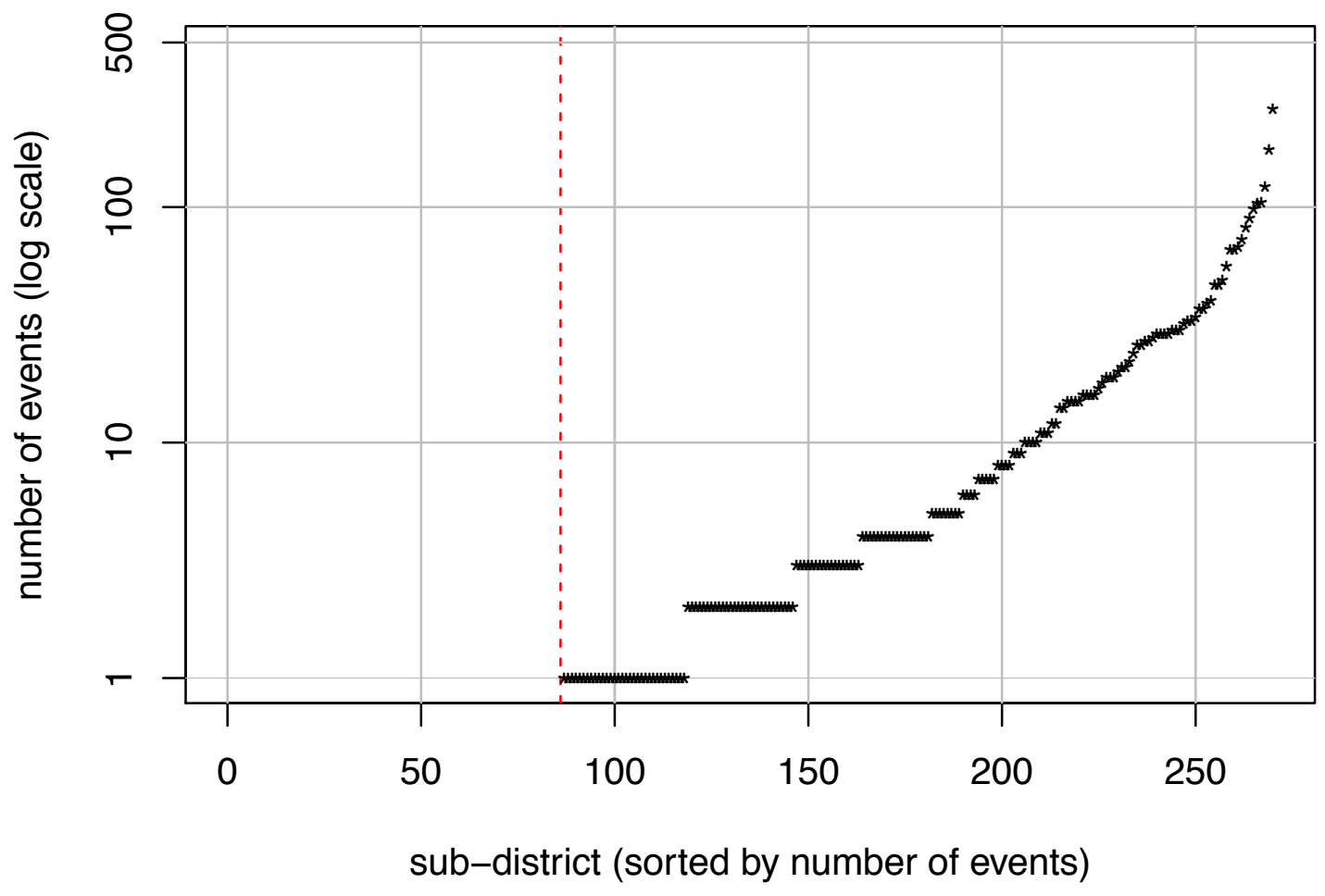

(b) GDELT machine-coded database $(\mathrm{n}=1397)$

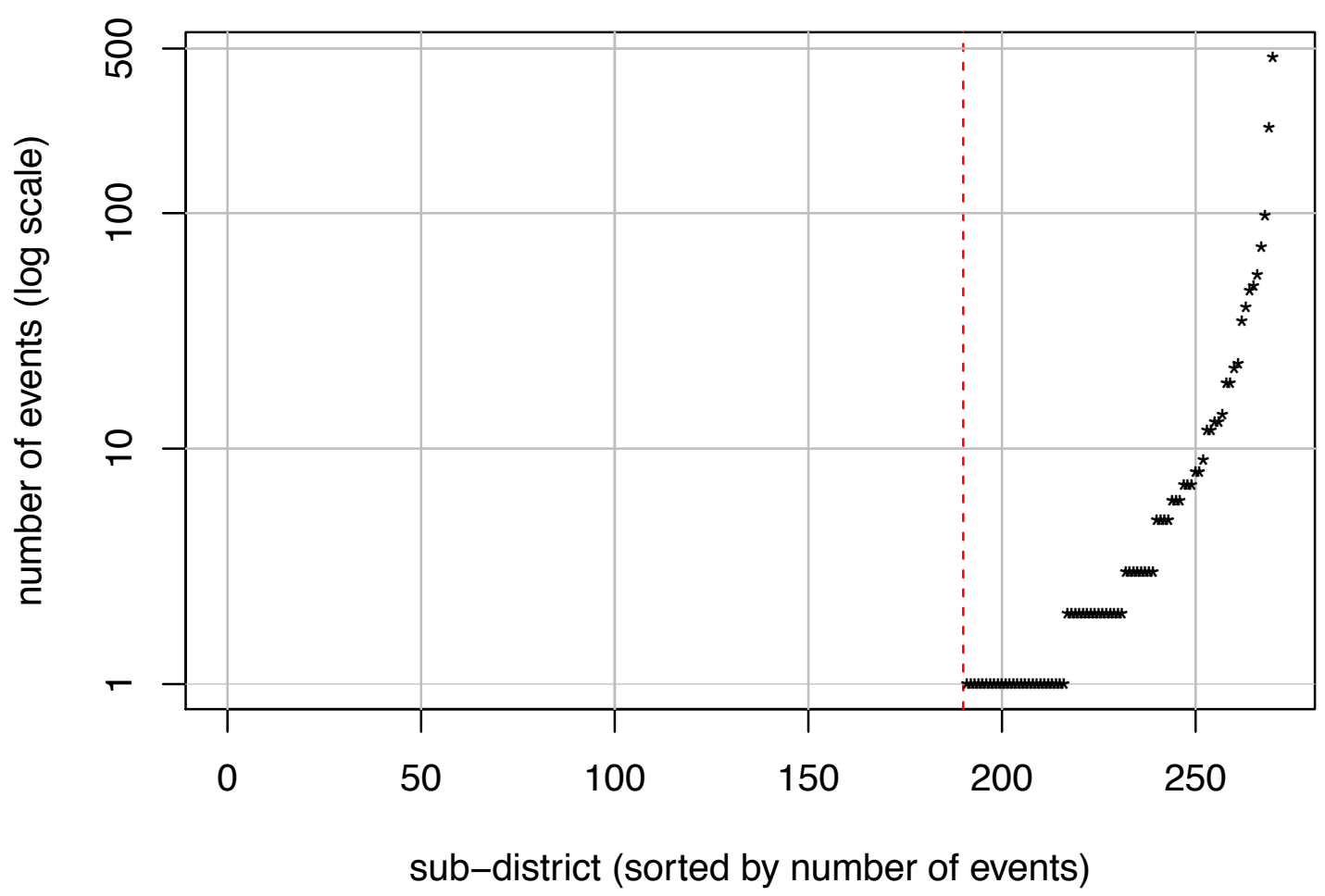

Notes: Each point represents total number of events in the databases for a given sub-district $(\mathrm{n}=266)$. Count includes challenger, regime, and ally actions. Databases track events through December 31, 2011. 


\section{ETHNIC IDENTITY CODING \\ Description of database}

Ethnic identity variables are taken from the "Syria Town Ethnicity Database," which I constructed jointly with Kheder Khaddour (Khaddour and Mazur, 2016). The expert interviews that form the basis of the ethnicity data were conducted between October 2013 and March 2014; respondents were asked about ethnic composition before 2011 (i.e. before any displacement occurred during conflict). Seventy-five were conducted in Gaziantep, Turkey, twenty in Amman, Jordan, twenty-five in Beirut, Lebanon, twenty in Istanbul, Turkey, and twenty via Skype. Research assistants were selected for their knowledge of and contacts in particular regions to ensure the quality of responses. Interview subjects were selected for their knowledge of a given area and located through networks of contacts from the relevant region. For one governorate, al-Hassakeh, a local research organization, al-Tajammua' al-wataniyya lil-shabab al-arabi (see Kulna Shuraka' 2013), produced in 2012 a town-level map using the same methods used in the authors' survey. This map was used as a basis for verification, rather than new coding; its results align with the description of the region given by Khalifa (2013).

A national level map plotting the Syria Town Ethnicity data is presented in figure A2; panel (a) plots all towns with equal size, whereas panel (b) plots towns by their built-up area, to indicate relative size of settlements.

Several sources were used to verify the coding done from expert interviews. Publicly available sources cannot not be used for town-level validation (ex. Izady 2013) because they describe general regions, rather than specific towns. Instead, a map produced and shared with the author privately by a researcher working for an international organization formed the primary basis for comparison. Work by Khalifa (2013) and an online forum listing Druze towns (http://raia.ba7r.org/t1793-topic) were used for further validation. These maps, taken together, contained data for 1466 of the 5204 towns in the database (covering 72 percent of the total population).

To produce an alternate coding for robustness testing, all codings were viewed alongside one another and the majority identity of a town was changed from that in the author's database if contradicted by one of the sources; if one contradicted and another agreed with the original coding, the original coding was retained. This led to a recoding of 146 towns (in which 2 percent of the total Syrian population resided). The towns recoded were primarily small villages. The largest town to be recoded had 30,519 residents; ten recoded towns had between 10,969 and 20,301 residents, all others had fewer than 10,000, and seventy had fewer than 1000 residents.

The re-coding changed the ethnicity value for five events occurring in five different towns (out of a total of 879 events): four were spillover of violence from neighboring areas into minority towns, and one is a protest in a Sunni town (coded incorrectly in the alternative ethnic database as Christian), al-Bayda, in Tartous governorate. ${ }^{1}$

The negative binomial regression is re-fit with these modification to the original coding (table A1, specification 6). The results are statistically and substantively unchanged. These results lend support to the notion that ethnicity is accurately captured in the dataset.

One potential objection to the data collection strategy is that interview subjects will generalize from a region's most prominent town being known as a stronghold of a given ethnic group, and simply state that an entire area is populated by that group. The data collection strategywhich entailed choosing interview subjects from the sub-districts for which they provided information, with deep knowledge of their region — was designed to minimize the risk of imputing town identities from those of neighboring towns. Validation against extant sources (discussed above) suggests that this did not occur. Nonetheless, reader might conclude from the nearly-homogeneous

\footnotetext{
${ }^{1}$ News reports on protests and repression in 2011 (https://www.youtube.com/watch? $\mathrm{v}=\mathrm{ftSUqIdPEPU}$ ) and a 2013 massacre (http://www.telegraph.co.uk/news/worldnews/middleeast/syria/10036680/Syria-Sunni-village-massacred-inAlawite-heartland.html) confirm the ethnic identity of the town's residents.
} 
ethnic composition of regions like Sweida in figure A2 that coders simply inferred the identity of the whole region from a prominent town or two. Yet this impression reflects, in Sweida, at least, a reality documented by researchers who have conducted sustained on-the-ground research in these areas (ex. Roussel, 2009, p. 6; al-Aballah and al-Hallaq, 2017, ff14).

The considerable town-level heterogeneity appearing in the coding for several other regions known to have diverse populations lends further support to the notion that coding reasonably reflects town level identity characteristics. The Salamiya region west of Hama, for example, is characterized by such heterogeneity and its diversity is reflected in the data. Figure A3 depicts the diversity recorded in the ethnicity data, and further detail on the historical settlement of this area, consistent with patterns in the database, can be found in work by Darwish (2016, p. 1-5), Orient News (2015, p. 4-11), and Douwes and Lewis (1989, p. 216). 
Figure A2: Majority ethnic identity in Syria, by town

(a) all towns equal size

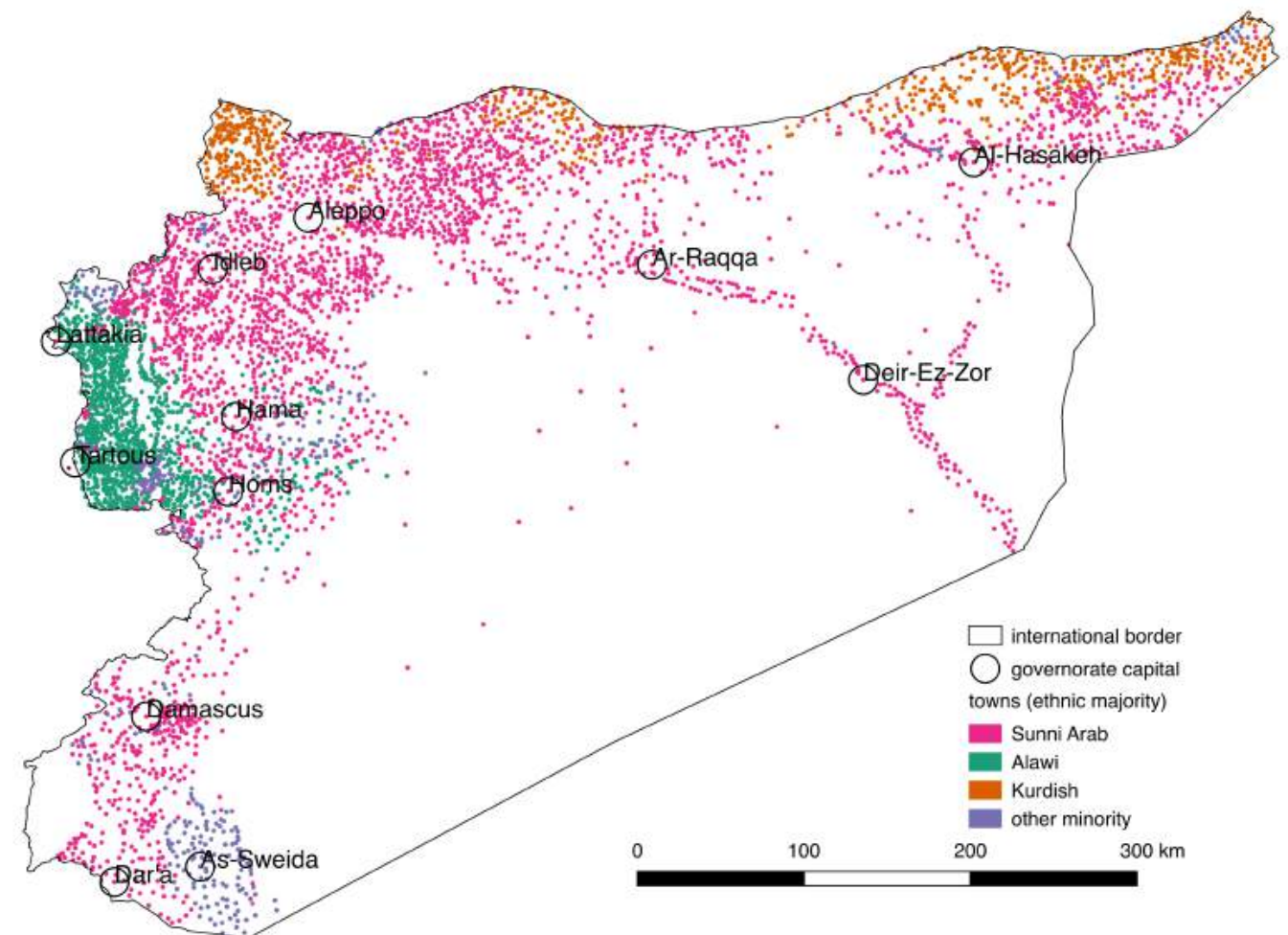

(b) by built up area

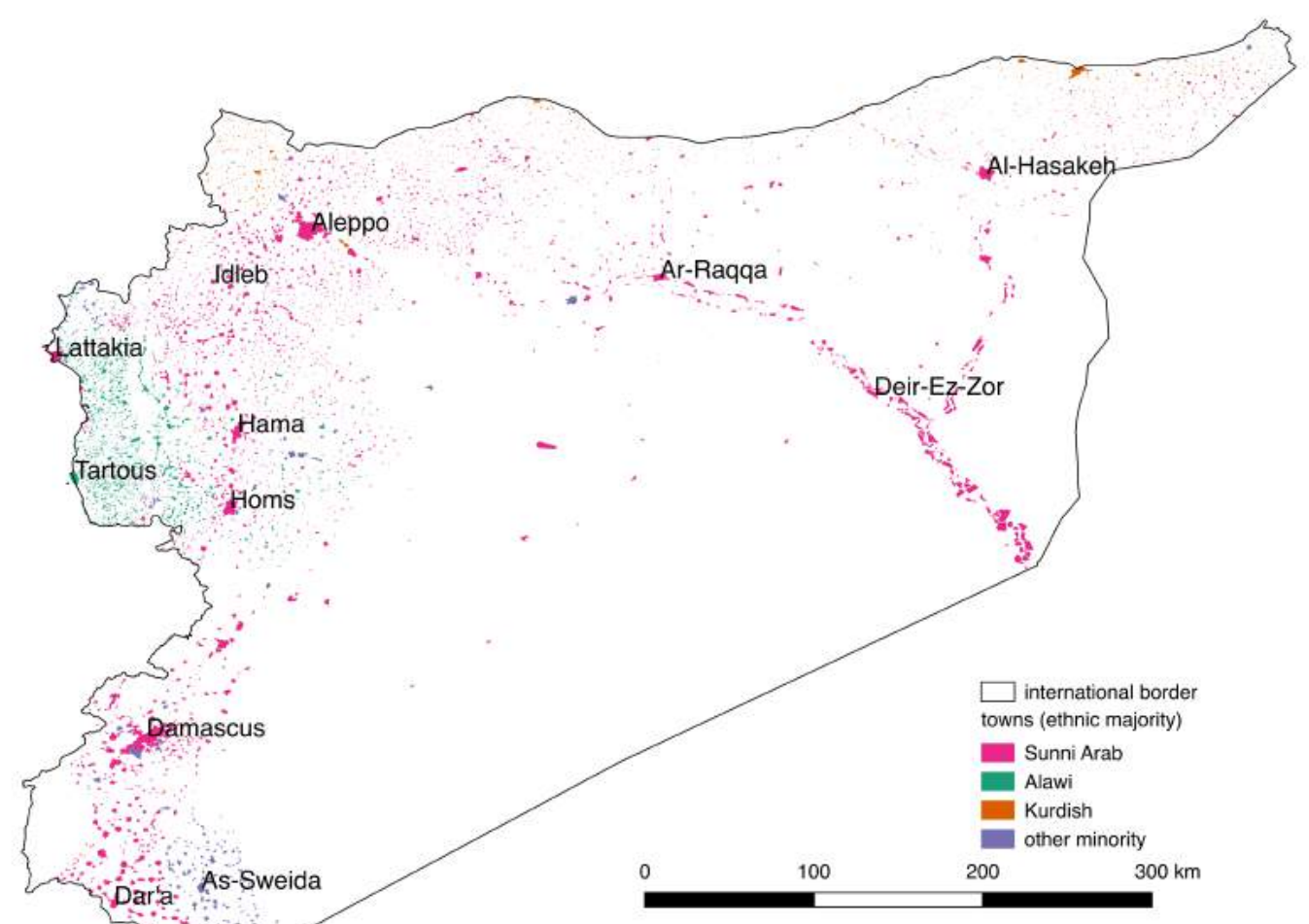


Figure A3: Majority ethnic identity in Hama governorate, by town (built up area)

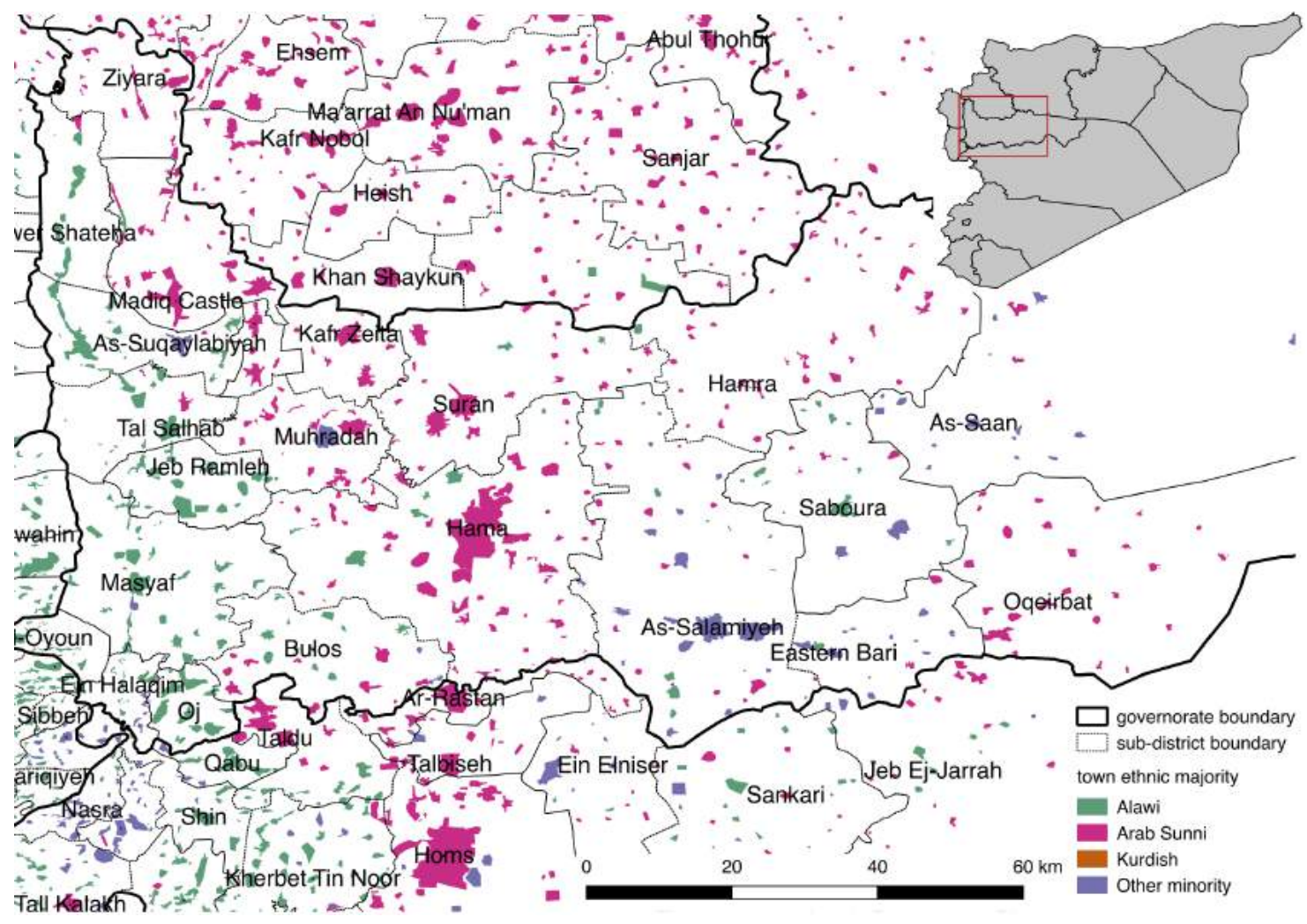




\section{ALTERNATE SPECIFICATIONS FOR NEGATIVE BINOMIAL REGRESSION}

Several alternate indicators for the grievance, opportunity, and local diversity hypotheses are employed in table A1. Specification 1 is the same as specification 3 in table 4 (the most focused test of the rival hypotheses) and later specifications in this table build upon it. To test local diversity hypotheses, Nearest 10 Alawi captures the notion of 'encirclement' by measuring the number of the ten closest towns to a given town that have an Alawi majority (specification 2). To test the grievance hypotheses, Total unemployment captures the percentage of a town population listed as unemployed in the 2004 census (3), and Adult illetracy captures the percentage of a town's adult population characterized as illiterate in the 2004 census (4). To test opportunity theories, Ruggedness is a measure of terrain roughness in a $5 \mathrm{~km}$ radius around a town's center, (calculated from NASA LP DAAC, 2013, specification 5). The alternate ethnicity coding is also included; specification 6 uses the author's coding plus modifications from outside sources. A nightlights measure is also included (specifications 7 and 8, see section IV of the appendix). Finally, as an alternate measure of tribal background, $200 \mathrm{~mm}$ rain line is a dummy variable capturing all areas getting less than $200 \mathrm{~mm}$ of rain per year (taken from Lewis, 1987, specification 9).

Table A2 includes measures of the percentage of a town's population with access to stateprovided water, electricity, and sewage services (taken from the 2004 census).

Finally, to address the risk that the ethnicity coding is systematically biased, table A3 fits the base models, restricting the sample by population size in two ways. First, to address the risk that ethnicity coders simply assigned the ethnic identity of large towns to neighboring small ones - and thereby flattened local diversity - towns with a population smaller than 1000 are excluded (specifications 1-5). Then, to address the risk that major cities' ethnic diversity is driving the result, towns with over 100,000 residents are also excluded (specifications 6-10). The results are substantively the same as in table 4 of the main text. 


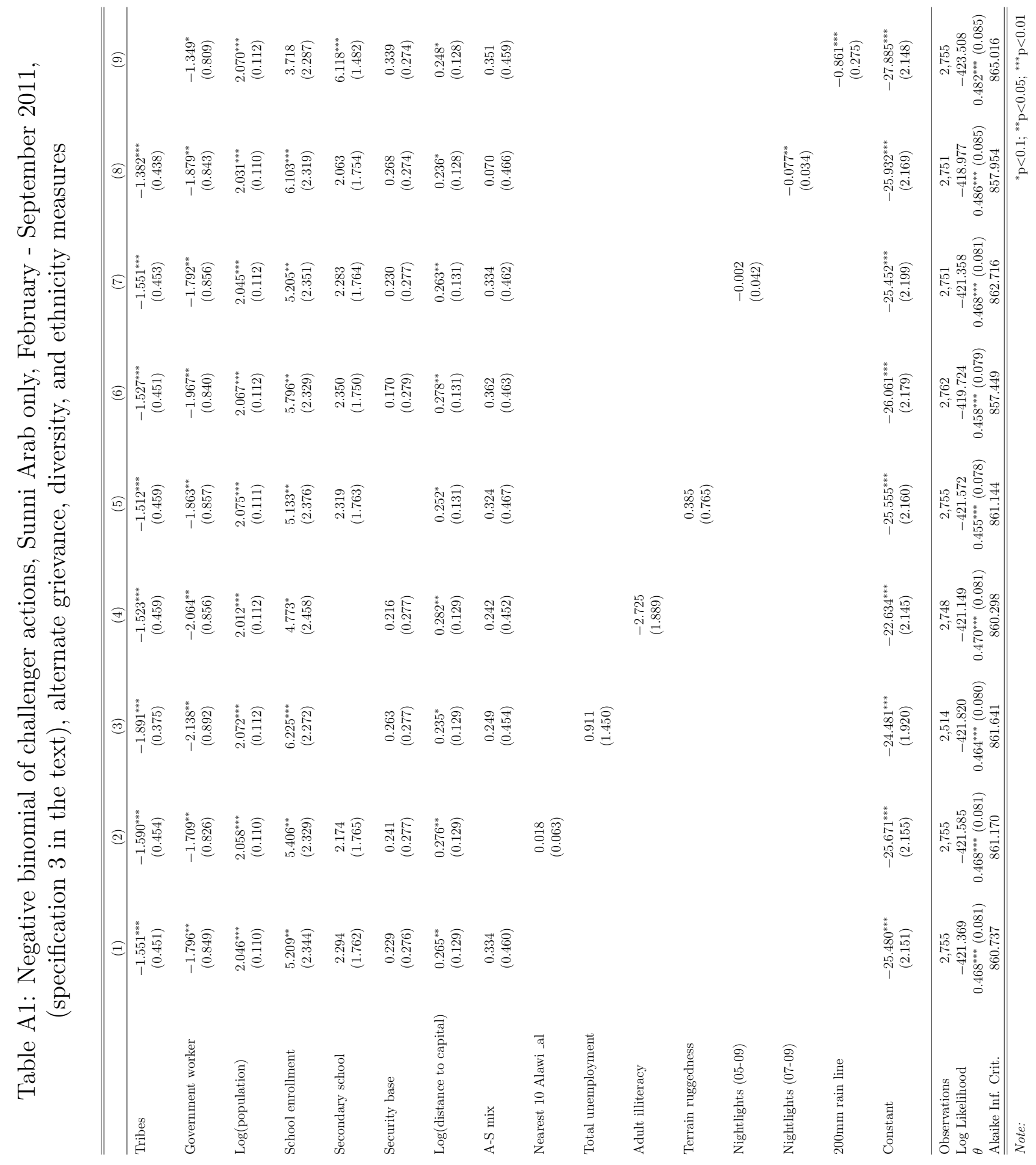


Table A2: Negative binomial of challenger actions, Sunni Arab only February - September 2011 (specification 3 in the text), with public goods measures

\begin{tabular}{|c|c|c|c|c|}
\hline & \multicolumn{4}{|c|}{ Dependent variable: } \\
\hline & \multicolumn{4}{|c|}{ cncs } \\
\hline & $(1)$ & $(2)$ & $(3)$ & $(4)$ \\
\hline Tribes & $\begin{array}{c}-1.551^{* * *} \\
(0.451)\end{array}$ & $\begin{array}{c}-1.564^{* * *} \\
(0.452)\end{array}$ & $\begin{array}{c}-1.549^{* * *} \\
(0.455)\end{array}$ & $\begin{array}{c}-1.562^{* * *} \\
(0.454)\end{array}$ \\
\hline Government worker & $\begin{array}{c}-1.796^{* *} \\
(0.849)\end{array}$ & $\begin{array}{c}-1.842^{* *} \\
(0.851)\end{array}$ & $\begin{array}{c}-1.782^{* *} \\
(0.862)\end{array}$ & $\begin{array}{c}-1.798^{* *} \\
(0.851)\end{array}$ \\
\hline $\log ($ population $)$ & $\begin{array}{c}2.046^{* * *} \\
(0.110)\end{array}$ & $\begin{array}{c}2.050^{* * *} \\
(0.111)\end{array}$ & $\begin{array}{c}2.043^{* * *} \\
(0.120)\end{array}$ & $\begin{array}{c}2.057^{* * *} \\
(0.115)\end{array}$ \\
\hline School enrollment & $\begin{array}{l}5.209^{* *} \\
(2.344)\end{array}$ & $\begin{array}{l}5.332^{* *} \\
(2.356)\end{array}$ & $\begin{array}{l}5.153^{* *} \\
(2.351)\end{array}$ & $\begin{array}{l}5.339^{* *} \\
(2.375)\end{array}$ \\
\hline Secondary school & $\begin{array}{c}2.294 \\
(1.762)\end{array}$ & $\begin{array}{c}2.371 \\
(1.763)\end{array}$ & $\begin{array}{c}2.307 \\
(1.826)\end{array}$ & $\begin{array}{c}2.378 \\
(1.783)\end{array}$ \\
\hline Security base & $\begin{array}{c}0.229 \\
(0.276)\end{array}$ & $\begin{array}{c}0.223 \\
(0.277)\end{array}$ & $\begin{array}{c}0.232 \\
(0.277)\end{array}$ & $\begin{array}{c}0.228 \\
(0.277)\end{array}$ \\
\hline $\log ($ distance to capital $)$ & $\begin{array}{l}0.265^{* *} \\
(0.129)\end{array}$ & $\begin{array}{l}0.261^{* *} \\
(0.129)\end{array}$ & $\begin{array}{l}0.263^{* *} \\
(0.130)\end{array}$ & $\begin{array}{l}0.267^{* *} \\
(0.129)\end{array}$ \\
\hline$\%$ resid. w. electricity & & $\begin{array}{l}-1.748 \\
(3.025)\end{array}$ & & \\
\hline$\%$ resid. w. sanitation & & & $\begin{array}{l}-0.051 \\
(0.445)\end{array}$ & \\
\hline$\%$ resid. w. water & & & & $\begin{array}{l}-0.280 \\
(0.899)\end{array}$ \\
\hline A-S mix & $\begin{array}{c}0.334 \\
(0.460)\end{array}$ & $\begin{array}{c}0.355 \\
(0.461)\end{array}$ & $\begin{array}{c}0.345 \\
(0.461)\end{array}$ & $\begin{array}{c}0.330 \\
(0.462)\end{array}$ \\
\hline Constant & $\begin{array}{c}-25.480^{* * *} \\
(2.151)\end{array}$ & $\begin{array}{c}-23.913^{* * *} \\
(3.381)\end{array}$ & $\begin{array}{c}-25.380^{* * *} \\
(2.214)\end{array}$ & $\begin{array}{c}-25.467^{* * *} \\
(2.146)\end{array}$ \\
\hline Observations & 2,755 & 2,676 & 2,232 & 2,568 \\
\hline Log Likelihood & -421.369 & -421.160 & -421.104 & -421.242 \\
\hline$\theta$ & $0.468^{* * *}(0.081)$ & $0.468^{* * *}(0.081)$ & $0.469^{* * *}(0.081)$ & $0.466^{* * *}(0.081)$ \\
\hline Akaike Inf. Crit. & 860.737 & 862.321 & 862.208 & 862.484 \\
\hline
\end{tabular}




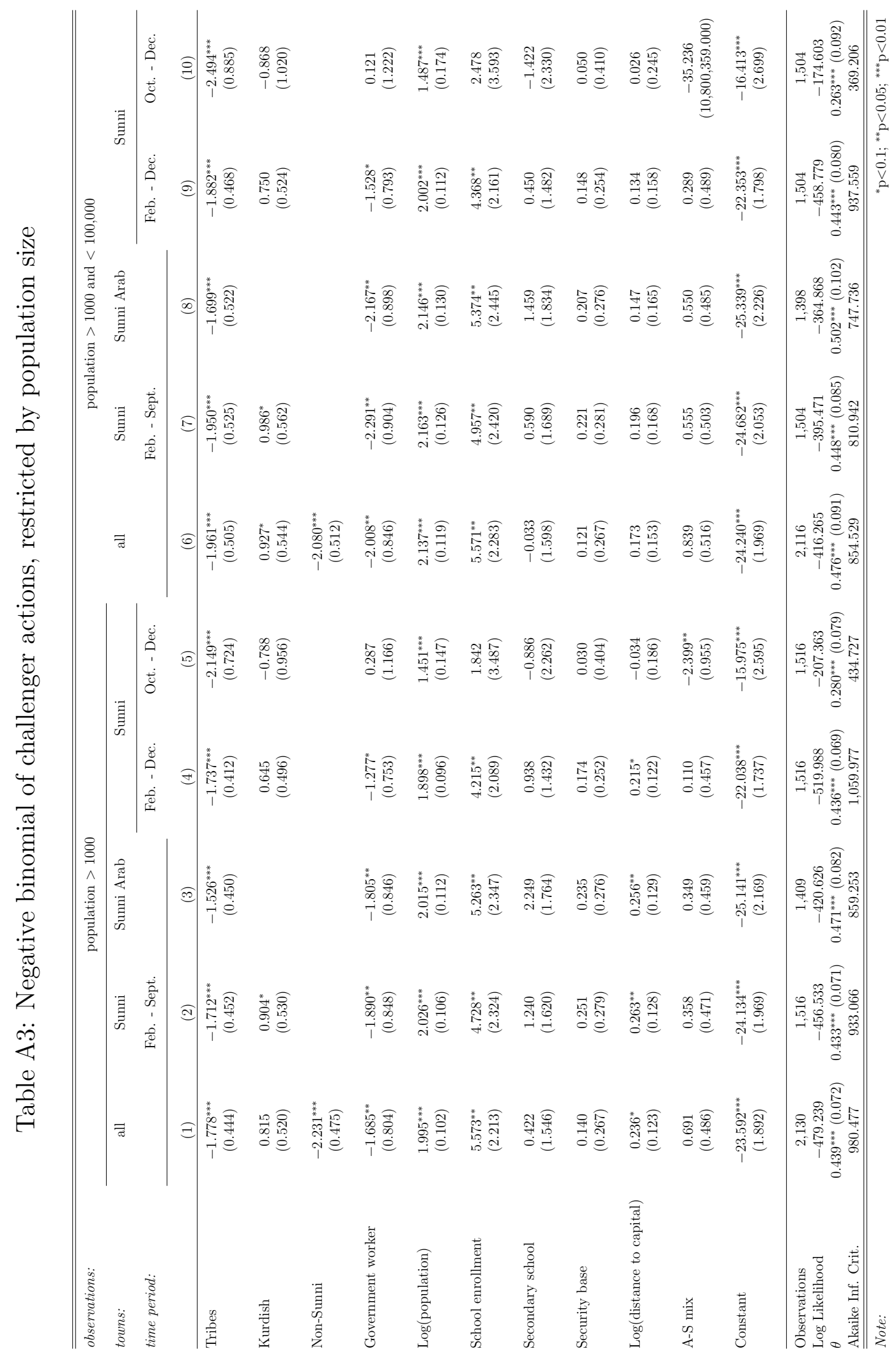




\section{NIGHTLIGHTS}

De Juan and Bank (2015) offer an additional alternate explanation incorporating both marginalization and state linkage elements. They argue that short-run change in patronage tiesoperationalized as the areas that experienced power cuts during periods of electricity grid load shedding and measured through satellite measure of nightlight emissions - explains patterns of contention. The results of that study differ from those presented here for several reasons.

First, nightlight fluctuation does not capture dynamics of state linkage or patronage in Syria. Whereas the unequal distribution of state jobs is a regular and well-documented grievance cited by revolution participants, there is no evidence to suggest that load shedding was viewed in a similar way; complaints in local newspapers described it only as bias towards urban centers (ex. al-Bunni, 2009). The available statistical evidence suggests that this perception reflected reality. Urban centers were spared the greatest cuts, but for reasons having nothing to do with clientelism. To wit, regime clients outside the center of the center of Damascus, in the spontaneous Alawi suburb of Mezze 86 and Dahiet Qudsayya (a suburb heavily populated by state employees), received power cuts. Meanwhile, the historically Sunni and oppositional old core of Lattakia did not see cuts- under the justification of "supporting tourism"- while other areas of this heavily Alawi governorate faced cuts (al-Bunni, 2009). This city-center bias in load shedding was the same in all other regions of country (personal correspondence with Ali Hamzeh, Professor of Electrical Engineering at Al Ahliyya Amman University, Jordan, September 16, 2017).

Town-level disaggregated data on nightlight change over time reinforce this notion. Suburbs and far-flung towns lose far more nightlight than major urban areas; the town-level map of Damascus and its surroundings in figure A4 is illustrative. The town-level patterns in the Damascus area raise the strong possibility that population movement accounts for these patterns - the city's eastern periphery (in the 10- to 20-kilometer radius) gains more nighlight over the 2004 to 2009 period than the city's central area and contiguous suburbs. This pattern, with greater gains on the city's periphery, is consistent with uniform power consumption growth across the metropolitan area (due to population increase) and nightlight saturation in the more developed city center (Hsu et al., 2015, p., 1871). While no population figures are available from after the 2004 census to definitively confirm this, anecdotal evidence indicates continued migration to the periphery of Damascus, Aleppo, and other large cities over the period under study (ex. Khalifa, 2018), that would also produce these nightlight patterns.

Even clearer evidence of population movement comes from the Alawi heartland; the drop in nightlight emissions in the coastal provinces is dramatic and stands at odds with all other data on patronage, which indicate heavy favoritism of this area. Eight of the top 10 and 15 of the top 20 subdistricts losing nightlights from 2007 to 2009 (the period examined in De Juan and Bank, 2015) are in Lattakia or Tartous governorates. al-Qardaha, the hometown of al-Asad family, was the eighth biggest loser of 261 total sub-districts. Moreover, a regression of nightlight change on town characteristics shows that Alawi areas lose the most nightlight, and governorate capitals are the least affected (see table A4). The Alawi bias in loss of nightlights suggests either extreme self-sacrifice on the part of the regime or, more likely, population movement; Balanche (2016) documents mass outmigration from rural Alawi areas to the periphery of cities.

Another possible explanation of these anomalous findings is measurement error; trends in power consumption over time consistently rise while nightlight emission falls. Though night light emissions decreased 20 percent over the time period measured, actual electricity consumption rose 10 percent (see table A5). Measurement error introduced by urban light saturation and satellite instrument fluctuation across years is compounded by aggregation over large territorial units, like the Syrian sub-districts employed in this study (Hsu et al., 2015, p. 1865-1869).

In addition, the dependent variable used by De Juan and Bank (2015) operationalization measures violence in civil war, while the outcome of interest is the challenge giving way to civil war onset. When the dependent variable is re-measured to better fit this concept, the results do not 
support their conclusions. The main empirical test in De Juan and Bank's (2015) article is a logistic regression of whether 25 or more deaths occurred in a sub-district from the beginning of the uprising until November 1, 2012. Eighty-five percent of the deaths in this database occur after January 1, 2012, under civil war conditions (author calculations from VDC data). For the reasons elaborated by Kalyvas (2006) and discussed in section III of this article's main text, including the civil war period introduces a form of 'post-treatment bias' to any attempt to assess the role of pre-conflict patronage structures on propensity for challenge. Only 36 of the 72 sub-districts coded by De Juan and Bank (2015) as ' 1 's on the outcome variable would still be coded this way if the time period were halted at January 1, 2012, and only 26 if halted at October 1, 2011. When these shorter periods are employed, the result does not hold (see table A6).

Finally, the main independent variable is measured for too short a time period, after the 'treatment' of load shedding has mostly already occurred. Load shedding began in 2006, jumping from $55 \mathrm{GwH}$ in 2005 to $345 \mathrm{GwH}$ in 2006 to $427 \mathrm{GwH}$ in 2007 (Beides et al., 2009, 27). When the time period for nightlight comparison is moved back to before load shedding began in earnest, from 2005 to 2009, this variable has no statistically significant effect in the model fit by the authors (see table A6). The extreme fluctuation in satellite measures between 2006 and 2008 (see table A7) is a likely cause for the anomalous finding. 
Table A4: Determinants of nightlights change,

OLS regression of change in annual DSMP-OLS average.

Unit of analysis: town.

\begin{tabular}{|c|c|c|c|c|c|c|c|c|c|c|}
\hline \multirow{3}{*}{$\begin{array}{l}\text { DV: } \\
\text { observations: }\end{array}$} & \multicolumn{5}{|c|}{ change 2004 to 2009} & \multicolumn{5}{|c|}{ change 2007 to 2009} \\
\hline & \multicolumn{3}{|c|}{ all } & \multicolumn{2}{|c|}{ coast only } & \multicolumn{3}{|c|}{ all } & \multicolumn{2}{|c|}{ coast only } \\
\hline & $(1)$ & $(2)$ & $(3)$ & $(4)$ & $(5)$ & $(6)$ & $(7)$ & $(8)$ & $(9)$ & $(10)$ \\
\hline $\log ($ population $)$ & $\begin{array}{c}-0.324^{* * *} \\
(0.038)\end{array}$ & $\begin{array}{c}-0.645^{* * *} \\
(0.088)\end{array}$ & $\begin{array}{c}-0.243^{* * *} \\
(0.094)\end{array}$ & $\begin{array}{c}-0.284^{* * *} \\
(0.107)\end{array}$ & $\begin{array}{l}-0.089 \\
(0.191)\end{array}$ & $\begin{array}{c}-0.667^{* * *} \\
(0.040)\end{array}$ & $\begin{array}{c}-0.513^{* * *} \\
(0.098)\end{array}$ & $\begin{array}{c}-0.314^{* * *} \\
(0.106)\end{array}$ & $\begin{array}{c}-0.318^{* *} \\
(0.144)\end{array}$ & $\begin{array}{l}-0.135 \\
(0.258)\end{array}$ \\
\hline$\%$ resid. with electr. & & $\begin{array}{c}2.893 \\
(1.889)\end{array}$ & $\begin{array}{c}2.804 \\
(1.874)\end{array}$ & & $\begin{array}{c}7.925 \\
(6.879)\end{array}$ & & $\begin{array}{l}-1.361 \\
(2.117)\end{array}$ & $\begin{array}{l}-1.382 \\
(2.128)\end{array}$ & & $\begin{array}{c}5.013 \\
(9.287)\end{array}$ \\
\hline$\%$ resid. with sewers. & & $\begin{array}{c}-1.280^{* * *} \\
(0.240)\end{array}$ & $\begin{array}{c}-1.154^{* * *} \\
(0.240)\end{array}$ & & $\begin{array}{c}-1.111^{* *} \\
(0.460)\end{array}$ & & $\begin{array}{c}-1.168^{* * *} \\
(0.269)\end{array}$ & $\begin{array}{c}-1.208^{* * *} \\
(0.272)\end{array}$ & & $\begin{array}{l}-0.874 \\
(0.620)\end{array}$ \\
\hline$\%$ wkfc. gov. wrkr & $\begin{array}{c}-0.391^{* *} \\
(0.196)\end{array}$ & $\begin{array}{c}2.106^{* * * *} \\
(0.684)\end{array}$ & $\begin{array}{c}1.926^{* * * *} \\
(0.679)\end{array}$ & $\begin{array}{c}-2.716^{* * *} \\
(0.398)\end{array}$ & $\begin{array}{c}2.436^{*} \\
(1.349)\end{array}$ & $\begin{array}{c}-1.321^{* * *} \\
(0.206)\end{array}$ & $\begin{array}{l}-0.712 \\
(0.767)\end{array}$ & $\begin{array}{l}-0.839 \\
(0.771)\end{array}$ & $\begin{array}{c}-4.246^{\text {*** }} \\
(0.537)\end{array}$ & $\begin{array}{l}-0.217 \\
(1.822)\end{array}$ \\
\hline road density & $\begin{array}{l}-0.014 \\
(0.164)\end{array}$ & $\begin{array}{l}-0.209 \\
(0.334)\end{array}$ & $\begin{array}{l}-0.221 \\
(0.331)\end{array}$ & $\begin{array}{c}-1.922^{* * *} \\
(0.404)\end{array}$ & $\begin{array}{c}-2.172^{\text {*** }} \\
(0.678)\end{array}$ & $\begin{array}{c}-1.588^{* * *} \\
(0.172)\end{array}$ & $\begin{array}{c}-2.220^{* * *} \\
(0.374)\end{array}$ & $\begin{array}{c}-2.168^{* * *} \\
(0.376)\end{array}$ & $\begin{array}{c}-3.513^{\text {*** }} \\
(0.545)\end{array}$ & $\begin{array}{c}-4.811^{* * *} \\
(0.916)\end{array}$ \\
\hline terr. ruggedness & $\begin{array}{c}-2.023^{* * *} \\
(0.260)\end{array}$ & $\begin{array}{c}-2.611^{* * *} \\
(0.483)\end{array}$ & $\begin{array}{c}-2.170^{* * * *} \\
(0.483)\end{array}$ & $\begin{array}{c}1.760^{* * * *} \\
(0.488)\end{array}$ & $\begin{array}{c}0.641 \\
(0.859)\end{array}$ & $\begin{array}{c}-1.622^{* * *} \\
(0.274)\end{array}$ & $\begin{array}{c}-1.803^{* * *} \\
(0.542)\end{array}$ & $\begin{array}{c}-1.647^{* * *} \\
(0.549)\end{array}$ & $\begin{array}{c}4.735^{* * * *} \\
(0.658)\end{array}$ & $\begin{array}{c}3.969^{* * * *} \\
(1.160)\end{array}$ \\
\hline$\%$ wkfc. mid. class & & $\begin{array}{c}-4.161^{* * *} \\
(1.122)\end{array}$ & $\begin{array}{c}-3.663^{* * *} \\
(1.113)\end{array}$ & & $\begin{array}{c}-7.471^{\text {*** }} \\
(2.184)\end{array}$ & & $\begin{array}{c}0.279 \\
(1.258)\end{array}$ & $\begin{array}{c}0.589 \\
(1.264)\end{array}$ & & $\begin{array}{c}-6.719^{* *} \\
(2.949)\end{array}$ \\
\hline \% w. univ. educ. & & $\begin{array}{l}-1.732 \\
(4.840)\end{array}$ & $\begin{array}{l}-0.146 \\
(4.795)\end{array}$ & & $\begin{array}{c}9.795 \\
(7.928)\end{array}$ & & $\begin{array}{c}-9.302^{*} \\
(5.424)\end{array}$ & $\begin{array}{l}-7.931 \\
(5.448)\end{array}$ & & $\begin{array}{c}18.910^{*} \\
(10.704)\end{array}$ \\
\hline Alawi maj. (binary) & $\begin{array}{c}-1.014^{* * *} \\
(0.136)\end{array}$ & $\begin{array}{c}-1.780^{* * *} \\
(0.261)\end{array}$ & $\begin{array}{c}-1.627^{* * *} \\
(0.259)\end{array}$ & $\begin{array}{l}-0.449 \\
(0.293)\end{array}$ & $\begin{array}{l}-0.506 \\
(0.471)\end{array}$ & $\begin{array}{c}-1.169^{* * *} \\
(0.143)\end{array}$ & $\begin{array}{c}-1.187^{* * *} \\
(0.292)\end{array}$ & $\begin{array}{c}-1.111^{* * *} \\
(0.294)\end{array}$ & $\begin{array}{l}-0.079 \\
(0.395)\end{array}$ & $\begin{array}{c}-0.603 \\
(0.636)\end{array}$ \\
\hline tribal Sunni maj. & & $\begin{array}{c}-0.908^{* * *} \\
(0.273)\end{array}$ & $\begin{array}{c}-0.654^{* *} \\
(0.272)\end{array}$ & & & & $\begin{array}{c}-1.334^{* * *} \\
(0.305)\end{array}$ & $\begin{array}{c}-1.224^{* * *} \\
(0.309)\end{array}$ & & \\
\hline Kurdish maj. & & $\begin{array}{c}-1.122^{* *} \\
(0.436)\end{array}$ & $\begin{array}{c}-0.776^{*} \\
(0.435)\end{array}$ & & & & $\begin{array}{c}-0.886^{*} \\
(0.489)\end{array}$ & $\begin{array}{l}-0.762 \\
(0.494)\end{array}$ & & \\
\hline Other minority maj. & & $\begin{array}{c}-1.887^{* * *} \\
(0.271)\end{array}$ & $\begin{array}{c}-1.705^{* * *} \\
(0.270)\end{array}$ & & & & $\begin{array}{c}-0.033 \\
(0.304)\end{array}$ & $\begin{array}{c}0.027 \\
(0.307)\end{array}$ & & \\
\hline Governorate capital & $\begin{array}{l}1.491^{*} \\
(0.882)\end{array}$ & $\begin{array}{c}3.937^{\text {*** }} \\
(0.981)\end{array}$ & & $\begin{array}{c}1.417 \\
(1.992)\end{array}$ & $\begin{array}{c}1.421 \\
(2.233)\end{array}$ & $\begin{array}{c}4.172^{* * *} \\
(0.926)\end{array}$ & $\begin{array}{c}4.719^{* * *} \\
(1.100)\end{array}$ & & $\begin{array}{c}3.829 \\
(2.684)\end{array}$ & $\begin{array}{c}3.380 \\
(3.015)\end{array}$ \\
\hline Sub-dist capital & & & $\begin{array}{c}-1.685^{\text {*** }} \\
(0.264)\end{array}$ & & & & & $\begin{array}{l}-0.359 \\
(0.300)\end{array}$ & & \\
\hline Constant & $\begin{array}{c}1.918^{* * *} \\
(0.263)\end{array}$ & $\begin{array}{l}3.350^{*} \\
(1.965)\end{array}$ & $\begin{array}{c}0.172 \\
(1.966)\end{array}$ & $\begin{array}{c}1.583^{*} \\
(0.856)\end{array}$ & $\begin{array}{l}-6.824 \\
(6.990)\end{array}$ & $\begin{array}{c}3.544^{* * * *} \\
(0.276)\end{array}$ & $\begin{array}{l}4.621^{* *} \\
(2.202)\end{array}$ & $\begin{array}{c}2.994 \\
(2.233)\end{array}$ & $\begin{array}{l}-0.561 \\
(1.153)\end{array}$ & $\begin{array}{l}-5.226 \\
(9.437)\end{array}$ \\
\hline Observations & 4,811 & 1,529 & 1,529 & 852 & 348 & 4,811 & 1,529 & 1,529 & 852 & 348 \\
\hline $\mathrm{R}^{2}$ & 0.076 & 0.170 & 0.184 & 0.131 & 0.131 & 0.180 & 0.128 & 0.118 & 0.186 & 0.190 \\
\hline Adjusted $\mathrm{R}^{2}$ & 0.075 & 0.163 & 0.177 & 0.125 & 0.105 & 0.179 & 0.120 & 0.110 & 0.181 & 0.166 \\
\hline
\end{tabular}

Population size and workforce variables from 2004 census, terrain ruggedness from NASA Aster L1B 2014, road density from UN OCHA 2010, ethnic majority variables from author database. 
Figure A4: Nightlight change ('04-'09), greater Damascus, at the town level
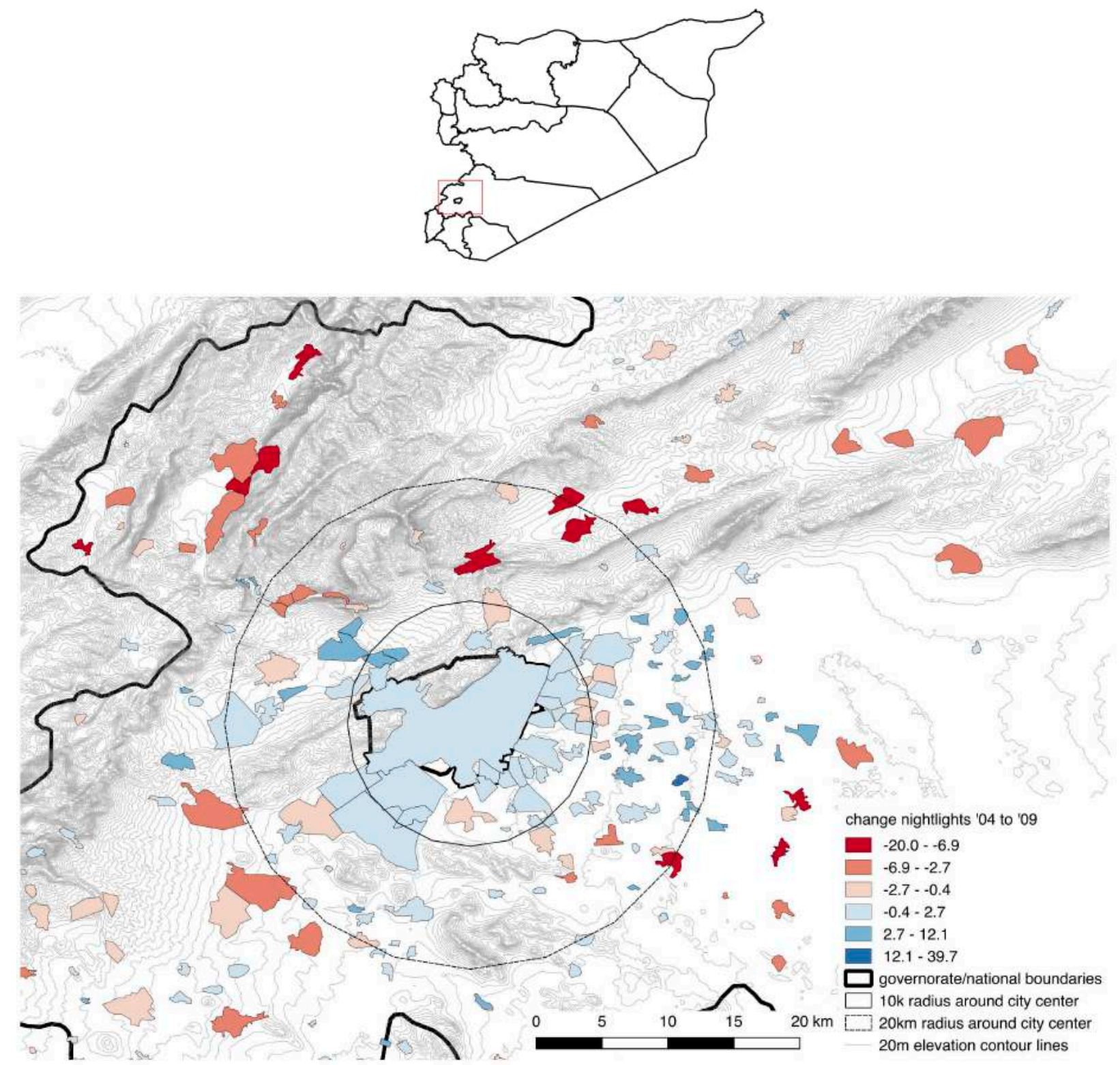

Notes: Nightlights data from DSMP-OLS, Average Visible, Stable Lights, \& Cloud Free Coverages, 2007 (NOAA 2013), polygons are built up areas to which town-level census units are attached, taken from UN OCHA 2017. 
Table A5: National-level night lights and electricity statistics

\begin{tabular}{cc|cc|c|ccc}
\hline year & $\begin{array}{c}\text { tot. output } \\
\text { (gwh) }\end{array}$ & $\begin{array}{c}\text { domestic } \\
\text { consump. (gwh) }\end{array}$ & $\begin{array}{c}\text { anuual } \\
\text { pct. chg. }\end{array}$ & $\begin{array}{c}\text { peak daily } \\
\text { supply (MW) }\end{array}$ & $\begin{array}{c}\text { nightlight } \\
\text { total }\end{array}$ & $\begin{array}{c}\text { nightlight } \\
\text { mean }\end{array}$ & $\begin{array}{c}\text { anuual } \\
\text { pct. chg. }\end{array}$ \\
\hline 2004 & & & & & 1022650 & 3.82 & \\
2005 & 34935 & 34093 & & 6008 & 894502 & 3.34 & -14.3 \\
2006 & 37504 & 36923 & 7.7 & 6739 & 1121711 & 4.19 & 20.3 \\
2007 & 38642 & 40560 & 9.0 & 7007 & 1181902 & 4.42 & 5.1 \\
2008 & 41023 & 42022 & 3.5 & 6715 & 1011711 & 3.78 & -16.8 \\
2009 & 42308 & 44521 & 5.6 & 7223 & 945193 & 3.53 & -7.0 \\
2010 & 46413 & 47232 & 5.7 & 8024 & & & \\
\hline
\end{tabular}

Sources: Electricity supply and consumption figures from Syrian Electricity Ministry Annual Reports, 2006-2011. Nightlights data from NOAA (2013), DSMP-OLS, 2004-2009. 
Table A6: Replication of DeJuan and Bank (2015) with alternate outcome variable specifications. Unit of analysis: sub-district.

\begin{tabular}{|c|c|c|c|c|c|c|}
\hline \multirow{3}{*}{$\begin{array}{l}\text { End time period: } \\
\text { Deaths threshold: }\end{array}$} & \multirow{3}{*}{$\begin{array}{l}\text { Nov. } 12 \\
(1)\end{array}$} & \multicolumn{3}{|c|}{ Jan. 12} & \multicolumn{2}{|c|}{ Oct. 11} \\
\hline & & \multicolumn{2}{|l|}{25} & \multirow{2}{*}{$\begin{array}{l}10 \\
(4)\end{array}$} & \multirow{2}{*}{$\begin{array}{l}25 \\
(5) \\
\end{array}$} & \multirow{2}{*}{$\begin{array}{l}10 \\
(6)\end{array}$} \\
\hline & & $(2)$ & (3) & & & \\
\hline sc_emplgov & $\begin{array}{l}-0.012 \\
(0.021)\end{array}$ & $\begin{array}{c}-0.052^{*} \\
(0.028)\end{array}$ & $\begin{array}{c}-0.053^{* *} \\
(0.021)\end{array}$ & $\begin{array}{l}-0.027 \\
(0.017)\end{array}$ & $\begin{array}{l}-0.027 \\
(0.024)\end{array}$ & $\begin{array}{l}-0.016 \\
(0.020)\end{array}$ \\
\hline sunni & $\begin{array}{c}0.369 \\
(0.742)\end{array}$ & $\begin{array}{l}-0.031 \\
(1.203)\end{array}$ & $\begin{array}{c}0.969 \\
(0.746)\end{array}$ & $\begin{array}{c}0.946 \\
(0.594)\end{array}$ & $\begin{array}{l}1.062 \\
(0.871)\end{array}$ & $\begin{array}{c}0.694 \\
(0.669)\end{array}$ \\
\hline alawites & $\begin{array}{l}-0.022 \\
(1.055)\end{array}$ & $\begin{array}{c}0.347 \\
(1.454)\end{array}$ & $\begin{array}{c}0.947 \\
(0.726)\end{array}$ & $\begin{array}{c}0.925 \\
(0.622)\end{array}$ & $\begin{array}{l}2.079^{* *} \\
(0.813)\end{array}$ & $\begin{array}{l}1.732^{* *} \\
(0.724)\end{array}$ \\
\hline sc_enroll611 & $\begin{array}{l}-0.046 \\
(0.169)\end{array}$ & $\begin{array}{l}-0.340 \\
(0.293)\end{array}$ & $\begin{array}{c}0.349 \\
(0.267)\end{array}$ & $\begin{array}{l}0.301^{*} \\
(0.176)\end{array}$ & $\begin{array}{c}0.074 \\
(0.262)\end{array}$ & $\begin{array}{c}0.240 \\
(0.257)\end{array}$ \\
\hline log_border_dist & $\begin{array}{l}-0.003 \\
(0.321)\end{array}$ & $\begin{array}{l}1.180^{*} \\
(0.610)\end{array}$ & $\begin{array}{c}0.399 \\
(0.347)\end{array}$ & $\begin{array}{c}0.096 \\
(0.264)\end{array}$ & $\begin{array}{l}-0.125 \\
(0.379)\end{array}$ & $\begin{array}{l}-0.086 \\
(0.314)\end{array}$ \\
\hline share_urban_2004 & $\begin{array}{c}2.932^{* * *} \\
(0.992)\end{array}$ & $\begin{array}{l}2.528^{* *} \\
(1.284)\end{array}$ & $\begin{array}{l}2.378^{* *} \\
(1.030)\end{array}$ & $\begin{array}{c}2.714^{* * *} \\
(0.882)\end{array}$ & $\begin{array}{c}2.424^{*} \\
(1.253)\end{array}$ & $\begin{array}{c}3.353^{* * *} \\
(1.076)\end{array}$ \\
\hline sc_electricity & $\begin{array}{l}-0.008 \\
(0.112)\end{array}$ & $\begin{array}{l}0.855^{* *} \\
(0.414)\end{array}$ & $\begin{array}{l}0.457^{*} \\
(0.254)\end{array}$ & $\begin{array}{l}-0.049 \\
(0.079)\end{array}$ & $\begin{array}{c}0.348 \\
(0.293)\end{array}$ & $\begin{array}{c}0.043 \\
(0.196)\end{array}$ \\
\hline sc_malunempl & $\begin{array}{l}-0.009 \\
(0.055)\end{array}$ & $\begin{array}{c}0.092 \\
(0.082)\end{array}$ & $\begin{array}{c}0.013 \\
(0.048)\end{array}$ & $\begin{array}{l}-0.006 \\
(0.040)\end{array}$ & $\begin{array}{l}-0.079 \\
(0.073)\end{array}$ & $\begin{array}{l}-0.087 \\
(0.062)\end{array}$ \\
\hline road_density & $\begin{array}{c}-2.590^{* *} \\
(1.250)\end{array}$ & $\begin{array}{l}-0.223 \\
(1.415)\end{array}$ & $\begin{array}{c}0.256 \\
(0.921)\end{array}$ & $\begin{array}{l}-0.089 \\
(0.932)\end{array}$ & $\begin{array}{l}-0.455 \\
(0.973)\end{array}$ & $\begin{array}{c}0.111 \\
(0.997)\end{array}$ \\
\hline log_pop_2004 & $\begin{array}{c}1.932^{* * *} \\
(0.465)\end{array}$ & $\begin{array}{c}3.094^{* * *} \\
(0.832)\end{array}$ & $\begin{array}{c}1.205^{* * *} \\
(0.392)\end{array}$ & $\begin{array}{c}1.005^{* * *} \\
(0.334)\end{array}$ & $\begin{array}{c}1.245^{* * *} \\
(0.426)\end{array}$ & $\begin{array}{c}1.051^{* * *} \\
(0.374)\end{array}$ \\
\hline ligmean_change_0907 & $\begin{array}{c}-0.464^{* * *} \\
(0.151)\end{array}$ & $\begin{array}{l}-0.276 \\
(0.194)\end{array}$ & $\begin{array}{l}-0.120 \\
(0.126)\end{array}$ & $\begin{array}{l}-0.168 \\
(0.110)\end{array}$ & $\begin{array}{l}-0.175 \\
(0.136)\end{array}$ & $\begin{array}{l}-0.159 \\
(0.126)\end{array}$ \\
\hline Constant & & & $\begin{array}{c}-96.017^{* * *} \\
(34.322)\end{array}$ & $\begin{array}{c}-38.716^{* *} \\
(17.460)\end{array}$ & $\begin{array}{l}-57.662 \\
(35.491)\end{array}$ & $\begin{array}{l}-41.790 \\
(28.214)\end{array}$ \\
\hline Observations & 260 & 260 & 260 & 260 & 260 & 260 \\
\hline $\mathrm{FE}$ & Y & Y & $\mathrm{N}$ & $\mathrm{N}$ & $\mathrm{N}$ & $\mathrm{N}$ \\
\hline Log Likelihood & -65.355 & -36.479 & -60.422 & -80.725 & -48.048 & -60.762 \\
\hline Akaike Inf. Crit. & 178.709 & 120.959 & 144.843 & 185.450 & 120.097 & 145.523 \\
\hline
\end{tabular}

Specification (1) is the exact model fit by De Juan and Bank (2015). It separates (on two governorates) due to the fixed effects, so fixed effects are not used in specifications (3) through (6). When fixed effects are included, separation occurs on 4 governorates in specification (4), 5 on (5), 4 on (6). 
Table A7: Replication of DeJuan and Bank (2015) with alternate nightlight years. Logistic regression of $>25$ deaths, Feb. 2011 - Nov. 2012. Unit of analysis: sub-district.

\begin{tabular}{|c|c|c|c|c|c|c|}
\hline & (1) & (2) & (3) & (4) & $(5)$ & (6) \\
\hline sc_emplgov & $\begin{array}{l}-0.012 \\
(0.021)\end{array}$ & $\begin{array}{l}-0.009 \\
(0.020)\end{array}$ & $\begin{array}{l}-0.007 \\
(0.020)\end{array}$ & $\begin{array}{l}-0.009 \\
(0.020)\end{array}$ & $\begin{array}{l}-0.008 \\
(0.021)\end{array}$ & $\begin{array}{l}-0.010 \\
(0.020)\end{array}$ \\
\hline sunni & $\begin{array}{c}0.369 \\
(0.742)\end{array}$ & $\begin{array}{c}0.416 \\
(0.699)\end{array}$ & $\begin{array}{c}0.400 \\
(0.695)\end{array}$ & $\begin{array}{c}0.367 \\
(0.728)\end{array}$ & $\begin{array}{c}0.359 \\
(0.741)\end{array}$ & $\begin{array}{c}0.324 \\
(0.713)\end{array}$ \\
\hline alawites & $\begin{array}{l}-0.022 \\
(1.055)\end{array}$ & $\begin{array}{l}-0.001 \\
(0.958)\end{array}$ & $\begin{array}{l}-0.025 \\
(0.957)\end{array}$ & $\begin{array}{l}-0.037 \\
(1.024)\end{array}$ & $\begin{array}{l}-0.012 \\
(1.037)\end{array}$ & $\begin{array}{l}-0.067 \\
(1.002)\end{array}$ \\
\hline sc_enroll611 & $\begin{array}{l}-0.046 \\
(0.169)\end{array}$ & $\begin{array}{c}0.033 \\
(0.165)\end{array}$ & $\begin{array}{c}0.037 \\
(0.166)\end{array}$ & $\begin{array}{l}-0.017 \\
(0.168)\end{array}$ & $\begin{array}{l}-0.055 \\
(0.170)\end{array}$ & $\begin{array}{c}0.008 \\
(0.170)\end{array}$ \\
\hline log_border_dist & $\begin{array}{l}-0.003 \\
(0.321)\end{array}$ & $\begin{array}{l}-0.203 \\
(0.306)\end{array}$ & $\begin{array}{l}-0.180 \\
(0.306)\end{array}$ & $\begin{array}{l}-0.026 \\
(0.315)\end{array}$ & $\begin{array}{l}-0.068 \\
(0.316)\end{array}$ & $\begin{array}{l}-0.161 \\
(0.306)\end{array}$ \\
\hline share_urban_2004 & $\begin{array}{c}2.932^{* * *} \\
(0.992)\end{array}$ & $\begin{array}{l}2.427^{* *} \\
(0.955)\end{array}$ & $\begin{array}{l}2.362^{* *} \\
(0.956)\end{array}$ & $\begin{array}{c}2.659^{* * *} \\
(0.965)\end{array}$ & $\begin{array}{c}2.876^{* * *} \\
(0.982)\end{array}$ & $\begin{array}{c}2.554^{* * *} \\
(0.957)\end{array}$ \\
\hline sc_electricity & $\begin{array}{l}-0.008 \\
(0.112)\end{array}$ & $\begin{array}{c}0.013 \\
(0.118)\end{array}$ & $\begin{array}{c}0.021 \\
(0.124)\end{array}$ & $\begin{array}{c}0.003 \\
(0.115)\end{array}$ & $\begin{array}{l}-0.010 \\
(0.110)\end{array}$ & $\begin{array}{c}0.013 \\
(0.119)\end{array}$ \\
\hline sc_malunempl & $\begin{array}{l}-0.009 \\
(0.055)\end{array}$ & $\begin{array}{c}0.001 \\
(0.051)\end{array}$ & $\begin{array}{c}0.001 \\
(0.050)\end{array}$ & $\begin{array}{l}-0.002 \\
(0.053)\end{array}$ & $\begin{array}{l}-0.006 \\
(0.054)\end{array}$ & $\begin{array}{c}-0.0002 \\
(0.053)\end{array}$ \\
\hline road_density & $\begin{array}{c}-2.590^{* *} \\
(1.250)\end{array}$ & $\begin{array}{c}-2.186^{* *} \\
(1.107)\end{array}$ & $\begin{array}{c}-2.276^{* *} \\
(1.117)\end{array}$ & $\begin{array}{c}-2.484^{* *} \\
(1.190)\end{array}$ & $\begin{array}{c}-2.665^{* *} \\
(1.261)\end{array}$ & $\begin{array}{c}-2.615^{* *} \\
(1.196)\end{array}$ \\
\hline log_pop_2004 & $\begin{array}{c}1.932^{* * *} \\
(0.465)\end{array}$ & $\begin{array}{c}2.055^{* * *} \\
(0.470)\end{array}$ & $\begin{array}{c}2.094^{* * *} \\
(0.474)\end{array}$ & $\begin{array}{c}2.016^{* * *} \\
(0.468)\end{array}$ & $\begin{array}{c}1.925^{* * *} \\
(0.466)\end{array}$ & $\begin{array}{c}2.098^{* * *} \\
(0.470)\end{array}$ \\
\hline ligmean_change_0907 & $\begin{array}{c}-0.464^{* * *} \\
(0.151)\end{array}$ & & & & & \\
\hline d0904 & & $\begin{array}{l}-0.075 \\
(0.187)\end{array}$ & & & & \\
\hline d0905 & & & $\begin{array}{l}-0.142 \\
(0.187)\end{array}$ & & & \\
\hline d0906 & & & & $\begin{array}{c}-0.360^{* *} \\
(0.142)\end{array}$ & & \\
\hline d0907 & & & & & $\begin{array}{c}-0.448^{* * *} \\
(0.157)\end{array}$ & \\
\hline d0908 & & & & & & $\begin{array}{c}-0.547^{* *} \\
(0.243)\end{array}$ \\
\hline Observations & 260 & 260 & 260 & 260 & 260 & 260 \\
\hline Log Likelihood & -65.355 & -70.577 & -70.364 & -67.263 & -66.284 & -68.076 \\
\hline Akaike Inf. Crit. & 178.709 & 189.155 & 188.727 & 182.526 & 180.569 & 184.153 \\
\hline
\end{tabular}

Specification (1) is the exact model fit by De Juan and Bank (2015). Nightlights data for specifications (2) through (6) from NOAA (2013). 


\section{ADDITIONAL REFERENCES}

al-Abdallah, A., \& al-Hallaq, A. A. (2017, July 15). Duruz Suriya [The Druze of Syria]. AlJumhuriya. Retrieved from http://aljumhuriya.net/36883

al-Bunni, Y. (2009, August 12). Taqnin al-kahraba' bayn al-'ashwa'iyya wa-ina'dam al-halul altaqnin idhlal 1-al-mawatin akthar min ma huwwa khutta li-tawfir al-taqa [Electricity load shedding between randomness and lack of solutions: humiliation of citizens more than a plan to distribute electricity]. Kassioun. Retrieved from http://wwe.kassiounpaper.com/syria/item/28678-2016-11-30-00-57-08

Balanche, F. (2016). "Go to Damascus, my son": Alawi demographic shifts under Ba'ath Party rule. In M. Kerr \& C. Larkin (Eds.), The Alawis of Syria: war, faith and politics in the Levant (pp. 78-106). New York: Oxford University Press.

Beides, H., Covindassamy, A., Alshraih, W., Busz, H., \& Boukantar, K. (2009). Syrian Arab Republic Electricity Sector Strategy Note (No. 49923-SY). World Bank Energy Sector Management Assistance Program (ESMAP). Retrieved from https://openknowledge.worldbank.org/handle/10986/18896

Douwes, D., \& Lewis, N. N. (1989). The Trials of Syrian Isma ilis in the First Decade of the 20th Century. International Journal of Middle East Studies, 21(2), 215-232.

Hsu, F.-C., Baugh, K. E., Ghosh, T., Zhizhin, M., \& Elvidge, C. D. (2015). DMSP-OLS Radiance Calibrated Nighttime Lights Time Series with Intercalibration. Remote Sensing, 7(2), 18551876.

Khalifa, M. (2013). The impossible partition of Syria. Arab Reform Initiative. Retrieved from http://www.arab-reform.net/en/file/562/download?token=DImggNO9

Khalifa, O. (2018, February 9). Harasta, kaman wa kaman [Harasta again and again]. Al-Jumhuriya. Retrieved from https://www.aljumhuriya.net/ar/content/حرستا-كمان-وكمان

Kulna Shuraka'. (2013, August 16). Dirasa hama hawl al-tawazzu' al-sukkani fi mohafadhat alhassaka al-souriyya [Important study about population distribution in the Hassakeh governorate of Syria]. All4Syria. Retrieved from http://all4syria.info/Archive/93123

Leetaru, K., \& Schrodt, P. (2013). GDELT: Global Data on Events, Language, and Tone, 1979-2012. Presented at the International Studies Association Annual Conference, San Diego, CA. Retrieved from http://gdelt.utdallas.edu/about.html

Lewis, N. N. (1987). Nomads and Settlers in Syria and Jordan, 1800-1980. New York: Cambridge University Press.

NASA Land Processes Distributed Active Archive Center (LP DAAC). (2013). ASTER L1B. USGS/Earth Resources Observation and Science (EROS) Center. Retrieved from https://pdaac.usgs.gov

National Oceanic and Atmospheric Administration. (2013). Version 4 DMSP-OLS Nighttime Lights Time Series. Retrieved from http://ngdc.noaa.gov/eog/dmsp/downloadV4composites.html 
Orient News. (2015). al-Isma 'iliun fil-thawra al-suriyya... [Isma'ilis in the Syrian revolution...] (Orient Vision for Research and Studies). Retrieved from http://orient-

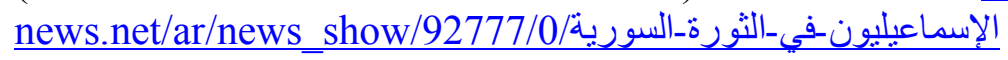

Ortiz, D., Myers, D., Walls, E., \& Diaz, M.-E. (2005). Where Do We Stand with Newspaper Data? Mobilization: An International Quarterly, 10(3), 397-419.

Roussel, C. (2009). La frontière communautaire entre druzes et sunnites en Syrie. Une fragmentation socio-spatiale instrumentée par le pouvoir politique. EchoGéo, (8).

Syrian Electricity Ministry. (2006, 2011). al-Taqrir al-ihsa'i al-sanawi [Annual statistical report]. Retrieved from http://www.moe.gov.sy/userfiles/file/Statistical\%20reports/reports_2006.pdf

Tilly, C. (1995). Popular Contention in Great Britain, 1758-1834. Cambridge, Mass: Harvard University Press.

Tilly, C. (2002). Event Catalogs as Theories. Sociological Theory, 20(2), 248-254.

UN Office for the Coordination of Humanitarian Assistance. (2017, June 1). OCHA's Common Operational Datasets for Syria. Retrieved from https://data.humdata.org/dataset/syrian-arabrepublic-administrative-boundaries-populated-places

Weidmann, N. B. (2015). On the Accuracy of Media-based Conflict Event Data. Journal of Conflict Resolution, 59(6), 1129-1149.

Weidmann, N. B., \& Rød, E. G. (2015). Making uncertainty explicit Separating reports and events in the coding of violence and contention. Journal of Peace Research, 52(1), 125-128. 